U.S. Department of the Interior

U.S. Geological Survey

\title{
Sodium Carbonate Resources of the Green River Formation
}

By

John R. Dyni

Denver, Colorado

\section{Open-File Report 96-729}

This report is preliminary and has not been reviewed for conformity with U.S. Geological Survey editorial standards (or with the North American Stratigraphic Code). Any use of trade, product, or firm names is for descriptive purposes only and does not imply endorsement by the U.S. Government. 


\title{
Sodium Carbonate Resources of the Green River Formation
}

\author{
By \\ John R. Dyni \\ U.S. Geological Survey \\ Box 25046, M.S. 939 \\ Denver Federal Center, CO 80225
}

\begin{abstract}
Marly lacustrine rocks of the Eocene Green River Formation, which occupy parts of several basins in Wyoming, Colorado, and Utah, contain world-class resources of oil shale and sodium carbonate minerals. The formation contains the world's largest known resource of natural sodium carbonate as bedded trona $\left(\mathrm{Na}_{2} \mathrm{CO}_{3} \cdot \mathrm{NaHCO}_{3} \cdot 2 \mathrm{H}_{2} \mathrm{O}\right)$ in southwest Wyoming as well as the second largest known resource of sodium carbonate as bedded and nodular nahcolite $\left(\mathrm{NaHCO}_{3}\right)$ in northwest Colorado. Five companies currently mine three beds of trona in Wyoming and one company mines a bed of nahcolite in Colorado.

Other sodium carbonate minerals in the Green River Formation that may have future economic potential include dawsonite $\left(\mathrm{NaAl}(\mathrm{OH})_{2} \mathrm{CO}_{3}\right)$, eitelite $\left(\mathrm{Na}_{2} \mathrm{CO}_{3} \cdot \mathrm{MgCO}_{3}\right)$, and shortite $\left(\mathrm{Na}_{2} \mathrm{CO}_{3} \cdot 2 \mathrm{CaCO}_{3}\right)$. Several sodium carbonate brines in Utah and Wyoming may have economic value for soda ash and for water-soluble organic acids.
\end{abstract}




\section{INTRODUCTION}

The lacustrine Green River Formation of Eocene age, which occupies several sedimentary basins in Wyoming, Colorado, and Utah (fig. 1), has long been known for its oil shale resources but less so for its enormous deposits of sodium carbonate minerals. Large deposits of sodium carbonate salts occur in the three-state area. These deposits include relatively pure beds of trona, nahcolite, and eitelite; nonbedded aggregates, nodules, and crystals of nahcolite; microscopic crystals of dawsonite in oil shale; veinlets and crystals of shortite; and brines of which some are highly enriched in organic acids. Five sodium carbonate occurrences including two in Utah, one in Colorado, and two in Wyoming, are being mined or have potential economic value.

The occurrences include deposits of bedded trona in the Green River Basin in southwest Wyoming, deposits of nahcolite and dawsonite commingled with high-grade oil shale in the Piceance Creek Basin in northwest Colorado, and bedded sodium carbonate salts near the town of Duchesne in the Uinta Basin, northeast Utah. The formation also contains two sodium carbonate brines that may have potential economic value. One of these brines occurs in a confined aquifer, the Birds-nest zone, in the eastern Uinta Basin about 30 miles south and east of Vernal, Utah. The other sodium carbonate brine-noteworthy for its unusually high content of soluble organic matter-underlies several townships at shallow depths near the communities of Farson and Eden in the northeastern part of the Green River Basin, Wyoming (fig. 1).

In this paper, the geologic setting of the Green River Formation is presented and the economic geology of each of the five occurrences of sodium carbonate and their potential for commercial development is described. 


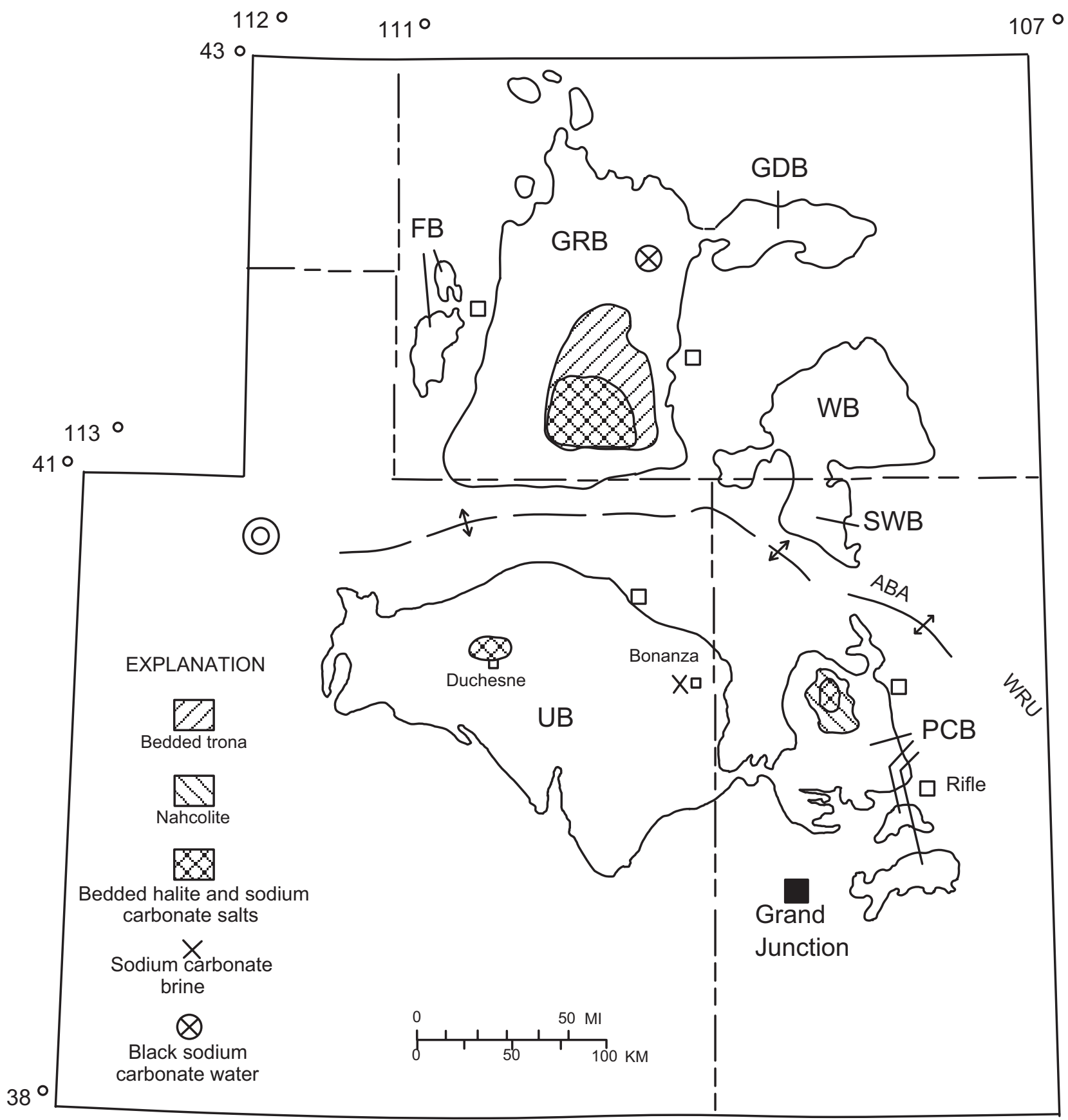

Figure 1. Map showing the areal distribution of the Green River Formation and the locations of five sodium carbonate deposits in Utah, Colorado, and Wyoming. ABA, Axial Basin Anticline; FB, Fossil Basin; GDB, Great Divide Basin; GRB, Green River Basin; PCB, Piceance Creek Basin; SWB, Sand Wash Basin; UB, Uinta Basin; UMU, Uinta Mountain Uplift; WB, Washakie Basin; WRU, White River Uplift. 


\section{GEOLOGIC SETTING}

Lacustrine sediments of the Eocene Green River Formation were deposited in two large lakes that occupied several lacustrine sedimentary-structural basins in Colorado, Wyoming, and Utah. These basins include the Green River, Washakie, and Sand Wash Basins in southwest Wyoming and northwest Colorado, the Piceance Creek Basin in northwest Colorado, and the Uinta Basin in northeast Utah (fig. 1). Lake Gosiute is the northern Eocene lake that occupied the Green River, Washakie, and Sand Wash Basins. The southern lake, Lake Uinta, occupied the Uinta and Piceance Creek Basins in Utah and Colorado. The Uinta Mountain Uplift, an east-west positive structural element, separated the two lakes, although they may have been connected during part of their existence on the east side of the uplift. At its maximum extent, Lake Uinta covered about 22,000 square miles $\left(57,000 \mathrm{~km}^{2}\right)$, and Lake Gosiute, about 15,000 square miles $\left(38,850 \mathrm{~km}^{2}\right)$. Together, the two Eocene lakes were somewhat larger than present-day Lake Erie and Lake Michigan combined. The drainage basins of the two lakes were probably double or more in size than the areas of the lakes at their maximum extent (fig. 2).

With the exception of tuffaceous sediments, the drainage basins of the Eocene lakes were the source of most of the Green River sediments. Volcanic tuffs were deposited directly into the lake and tuffaceous sediments also were washed into the lake from the surrounding drainage basin. Tuffaceous debris amounts to roughly 5 percent of the total sediments in the formation.

The glassy tuffaceous sediments readily decomposed in the alkaline lake waters and probably supplied some of the dissolved sodium and other cations that compose some of the authigenic carbonate minerals found in the formation.

The Green River Formation consists of a variety of lacustrine sedimentary rocks, including sandstone, claystone, shale, dolomitic marlstone, oil shale, and numerous, generally thin beds of volcanic tuff that were deposited in the two lakes. During much of Green River time, the lakes were closed with no outlets. During arid periods, the lakes became sufficiently saline to precipitate large quantities of sodium salts, either directly from the lake waters or interstitially from briny waters within the sediments. The most 


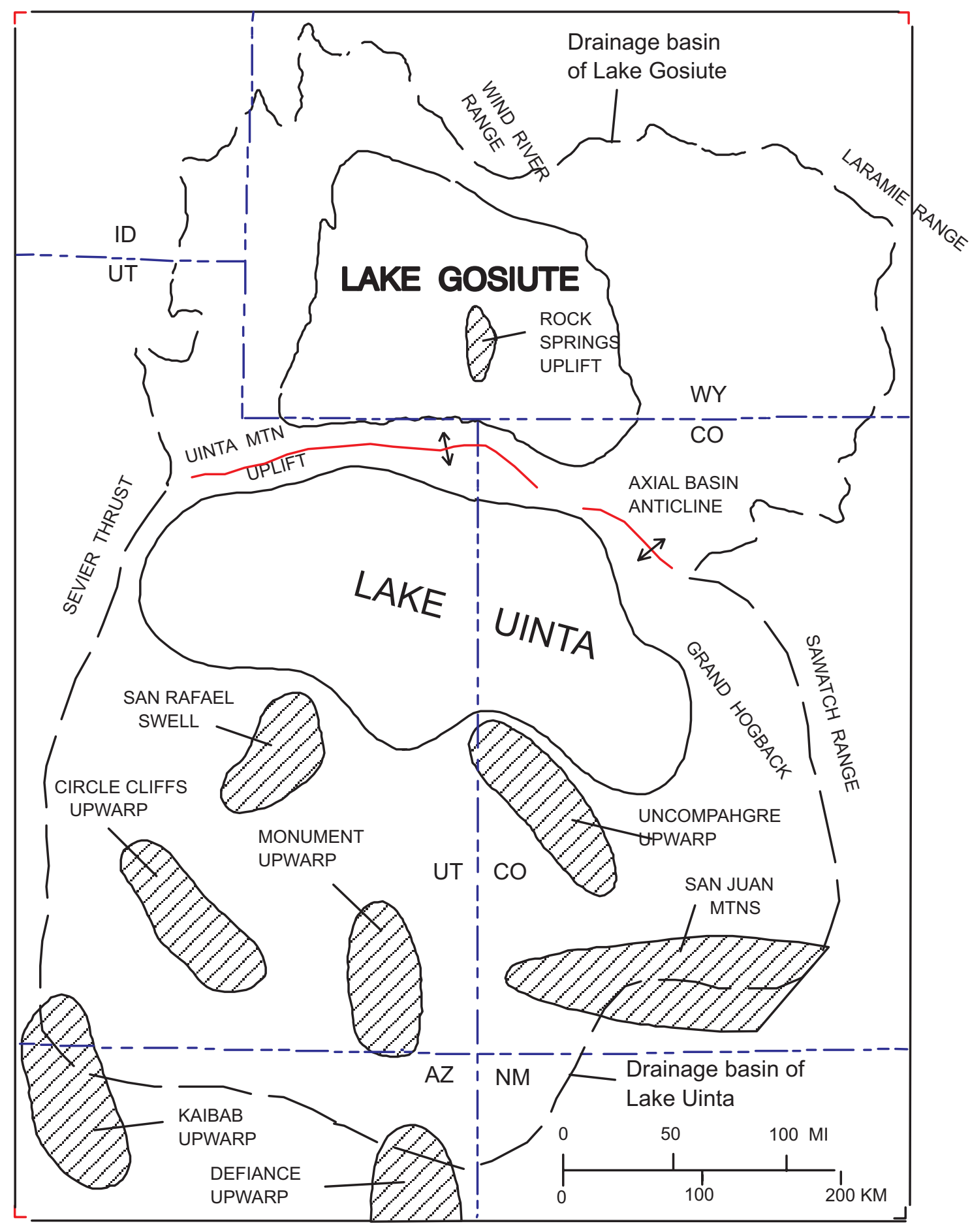

Figure 2. Paleogeographic map of the Green River lakes at their maximum extents and their approximate drainage basins. 
abundant of these salts include trona, nahcolite, shortite, dawsonite, halite, and less commonly eitelite and wegscheiderite.

Typically, the sediments grade from fine-grained sandstone, mudstone, claystone, and shale in shoreward areas of the lakes into carbonate-bearing sediments enriched in organic matter toward basin center. The lateral transition from siliciclastic to carbonateenriched rocks is also reflected in vertical sequences of the Green River Formation in the Green River, Piceance Creek, and Uinta Basins. This indicates increasing salinity of the alkaline lake waters as divalent cations of calcium and magnesium were precipitated as calcite, mg-calcite, and dolomite, while dissolved sodium, bicarbonate, and chloride continued to accumulate in waters in the deeper parts of the basins. Sulfate ion was essentially completely reduced by bacterial redox processes whereby bicarbonate was formed in the ratio of two moles of bicarbonate for each mole of sulfate that was reduced. Hydrolysis of detrital silicate minerals and glassy volcanic ash contributed additional dissolved bicarbonate, sodium, and other ions to the lake waters.

During their existence, the Green River lakes fluctuated widely in size in response to wet and dry climatic cycles. During three major dry periods, the lakes contracted sufficiently to precipitate sodium salts in basins in the three-state area. The first and most important dry cycle was during Wilkins Peak and Parachute Creek time when the vast deposits of trona and nahcolite were deposited in the Green River and Piceance Creek Basins, respectively. During two later dry periods, nahcolite in the Birds-nest zone was deposited in nodules and possibly some thin beds in eastern Uinta Basin, Utah. Finally, during a late dry period, bedded sodium salts were deposited in the Uinta Basin near Duchesne, Utah.

After deposition and lithification of the Green River sediments and their associated sodium carbonate deposits, ground waters dissolved some of these sodium minerals, as evidenced by the presence of solution breccias and solution cavities in drill cores recovered from exploratory wells drilled into the formation. In at least two areas, the Green River Formation contains sodium carbonate brines of unknown, but possibly exploitable, size that were probably formed by dissolution of sodium minerals by ground waters. 


\section{DUCHESNE SODIUM CARBONATE DEPOSIT}

The occurrence of abundant crystal molds of a then-unknown salt in exposures of marly sediments of the Green River Formation in eastern Uinta Basin and in the Piceance Creek Basin, lead W.H. Bradley (1931, plate 3) to define several "saline phases" in the formation. One of these "phases" included part of a sequence of marlstone and shale in the upper part of the formation in Indian Canyon, near Duchesne, Utah (fig. 1), which he designated the "barren and saline facies." Identification of one of the salts in the upper part of the Green River Formation in the Uinta Basin was first made by Erickson (1952), who reported the occurrence of shortite in drill core from the Sun Oil Company core hole located in sec. 22, T. 9 S., R. 20 E., Salt Lake Meridian, Uintah County, Utah, between the depths of 1975 and 2056 feet. Subsequently, Milton and others (1954) and Milton (1957) reported the occurrence of shortite and other authigenic minerals from bore holes in the Uinta Basin, including the new mineral, eitelite $\left(\mathrm{Na}_{2} \mathrm{CO}_{3} \cdot \mathrm{MgCO}_{3}\right)$. J.J. Fahey (Dane, 1955) identified shortite and nahcolite, possibly bedded, in cuttings from the Joseph Smith oil and gas test well 1 in sec. 16, T. 3 S., R. 5 W., a few miles north of Duchesne (figs. 3 and 4).

In 1970, Mapco Oil Company drilled the No. 1 Shrine Hospital well in the NE1/4SE1/4, sec. 10, T. 3 S., R. 5 W., about 4 miles north of Duchesne (figs. 3 and 4). Two sequences were cored between the depths of 4,140-4147 and 4,165-4,252 feet (1,2621,264 and 1,269-1,296 m). The lower core revealed three beds 2,6 , and 12 feet $(0.6,1.8$, and $3.7 \mathrm{~m}$ ) thick of halite (60-80 percent) mixed with varied amounts of wegscheiderite (20-40 percent) and minor amounts of marlstone. The lower core also revealed an additional six thin beds of mixed nahcolite, trona, wegscheiderite, and eitelite ranging from 0.3 to 1.5 feet in thickness (Dyni and others, 1985). 


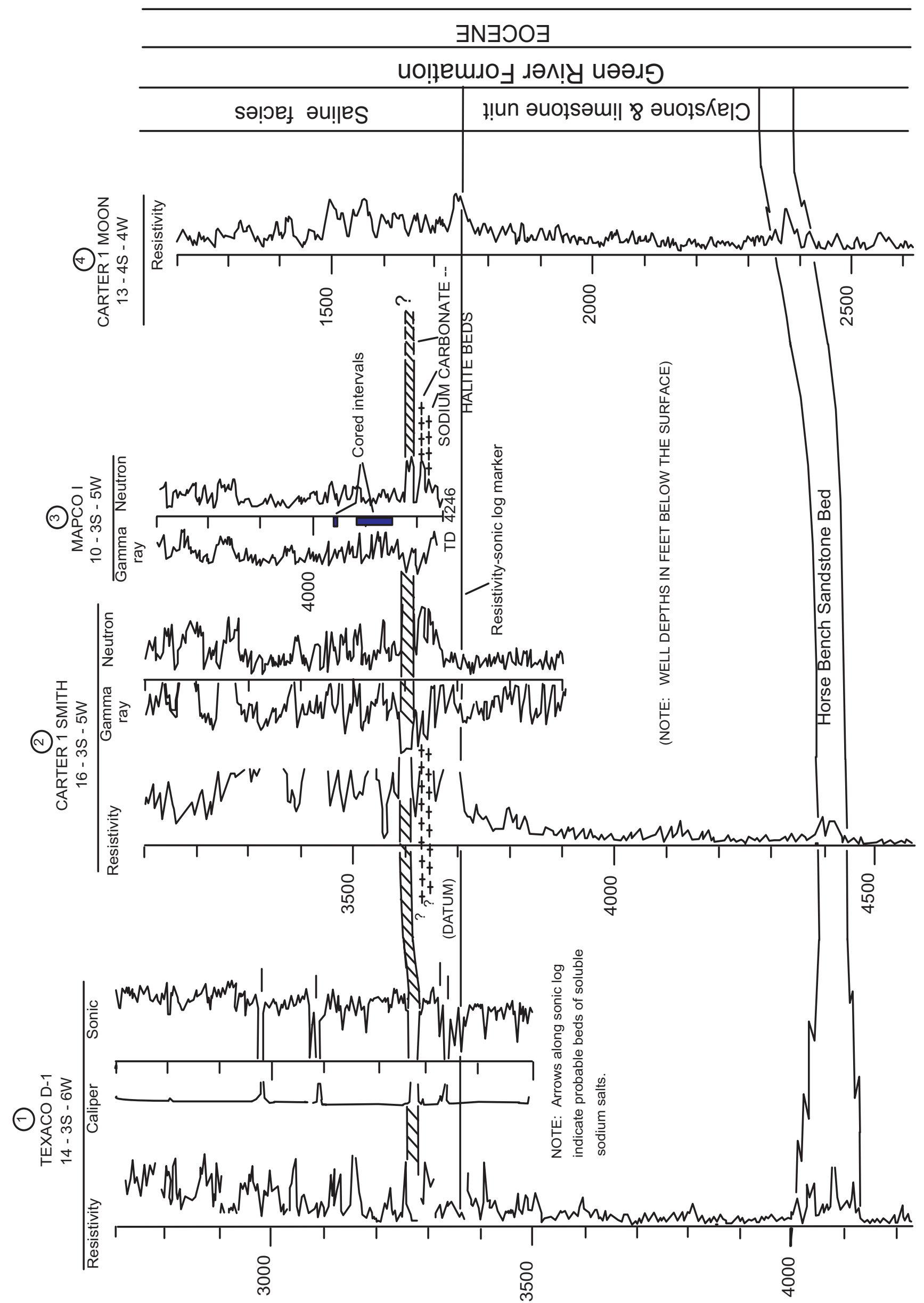

Figure 3. Stratigraphic cross section of the saline facies and underlying rocks in the upper part of the Green River Formation near Duchesne, Utah. Circled numbers above each drill hole are keyed to the line of stratigraphic section shown in fig. 4. Arrows point to possible evaporite beds. 


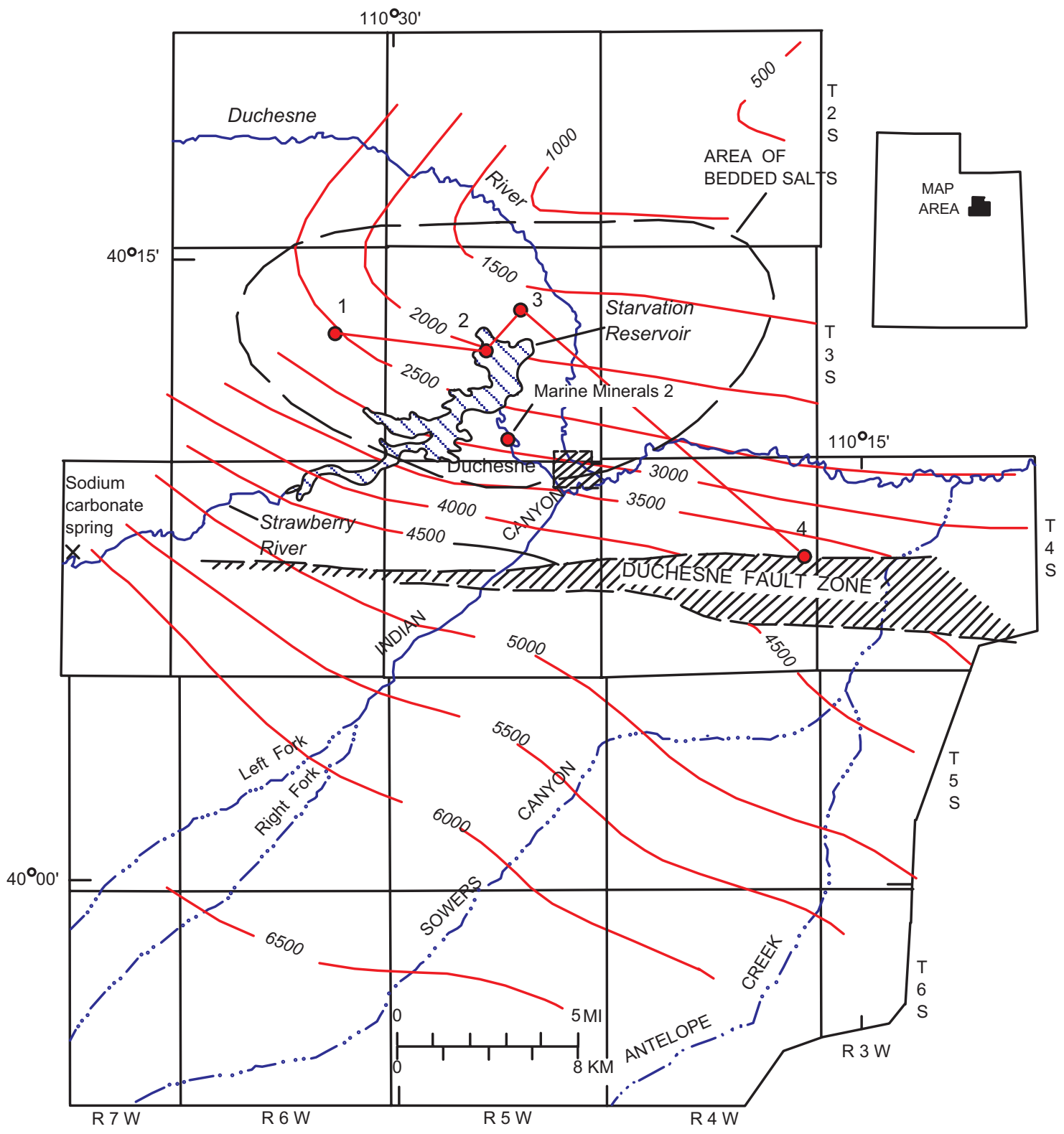

Figure 4. Map showing approximate limits of bedded sodium salts in the upper saline facies (heavy dashed line) near Duchesne, Utah, and line of stratigraphic section shown on fig. 3. Structure contours, in feet, drawn on a resistivity-sonic log datum near the base of the saline facies (see fig. 3). 
In 1973, the Duchesne deposit was further tested by Marine Minerals core hole 2 drilled in the $\mathrm{SE}^{1 / 4 \mathrm{NW}^{1} / 4}$ sec. 34, T. 3 S., R. 5 W., about one mile west of Duchesne (figs. 4 and 5). The bore hole was continuously cored from 50 to 2,857 feet ( 15 to $871 \mathrm{~m}$ ) below the surface. The top of a sequence of eitelite-bearing marly rocks, 20.7 feet $(6.3 \mathrm{~m})$ thick, was reached in this well at a depth of 2,743 feet $(836 \mathrm{~m})$ (fig. 5). A 4.8-foot-thick (1.5 $\mathrm{m})$ bed containing about 75 percent eitelite was found at a depth of 2,757 (840 m) feet. The net thickness of eitelite in the 20.7-foot-thick sequence of eitelitic rocks is about 6.9 $(2.1 \mathrm{~m}$ ) feet. The 4.5 -foot-thick $(1.4 \mathrm{~m})$ tuff in core hole 2 (fig. 5 ) is the same tuff (6 feet thick) identified as unit 11 in the Mapco No. 1 Shrine Hospital core hole (Dyni and others, 1985, fig. 4). Shortitic marlstone and other thin beds of mixed sodium carbonate salts and halite were also noted in core hole 2 . The core from this well is stored at the U.S. Geological Survey's Core Research Center, Lakewood, Colorado.

The bedded salts at Duchesne occur in the lower part of the saline facies of the Green River Formation as defined by Bradley (1931, pl. 9). In Indian Canyon south of Duchesne, the saline facies is about 1,100 feet $(335 \mathrm{~m})$ thick and its base is marked by a tuff 3 feet $(0.9 \mathrm{~m})$ thick (identified as a coarse-grained tuffaceous sandstone by Bradley, 1931, pl. 9, base of column D). This tuff may be the same as the thick tuff bed noted in the Mapco Shrine Hospital 1 well and in the Mapco core hole 2 (fig. 5).

The saline facies in Indian Canyon consists of fine-grained marly rocks including cherty marlstone, claystone, "mealstone," dolomite, limestone, and minor amounts of oil shale, sandstone, siltstone, and tuff. Mealstone is a name given to a marly rock containing abundant euhedral calcite crystals pseudmorphic after shortite. Water-soluble saline minerals appear to be especially abundant in the lower two-thirds of the saline facies. Although bedded salts were encountered in wells at Duchesne, no solution breccias marking the former presence of such beds were found on the outcrop in Indian Canyon (Dyni and others, 1985). Bryant and others (1989, pl. 1) have mapped the saline facies as far west as Twps. 8-9 S., R. 6 E., along the Wasatch-Utah County line about 45 miles west of Duchesne in about the same area where Dyni and others (1985, p. 53-54) noted crystal cavities in the unit. 


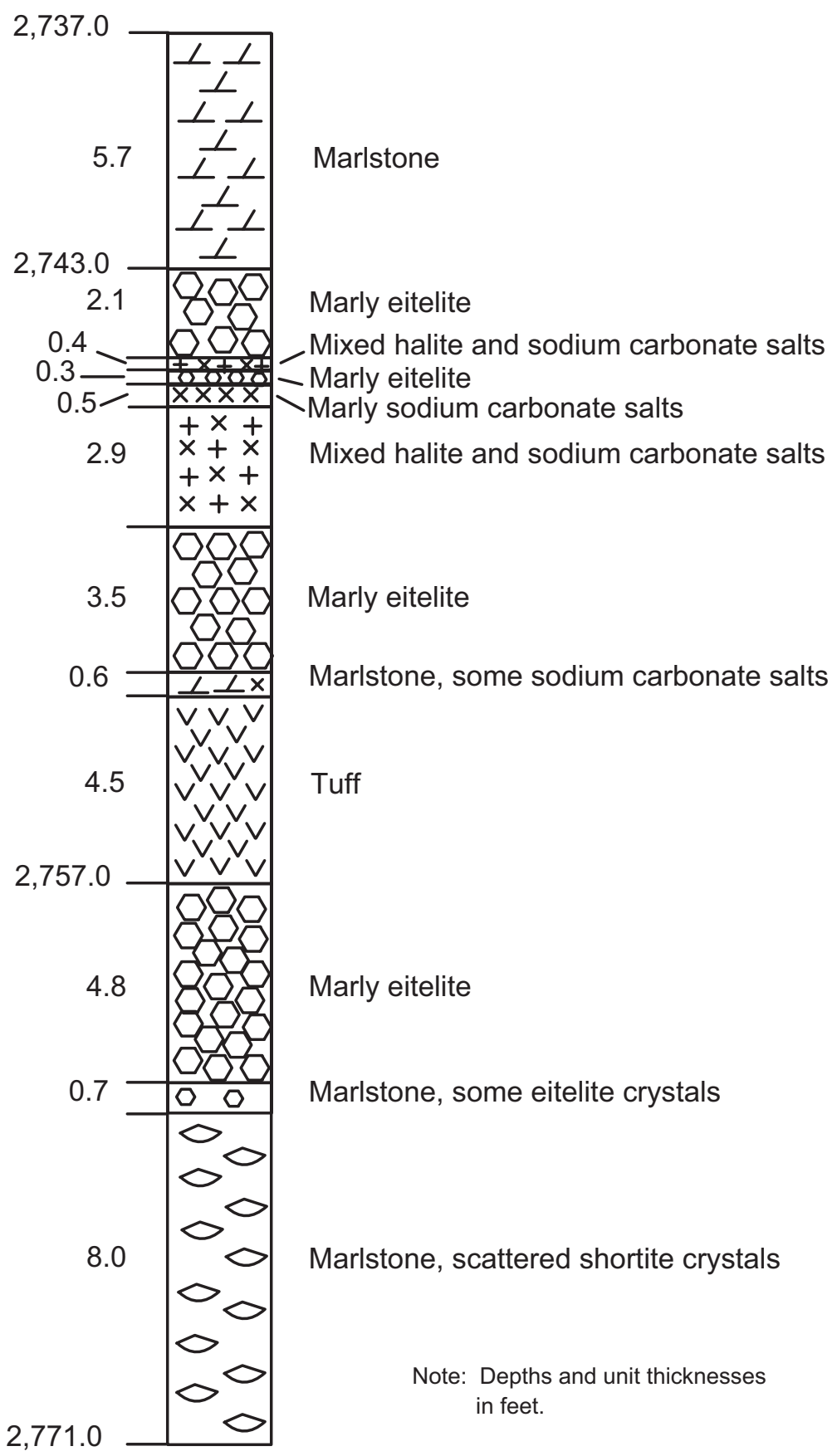

Figure 5. Generalized lithologic log of the bedded sodium carbonate salts and halite in the Marine Minerals core hole 2 in the SE1/4NW1/4 sec. 34, T.3 S., R.5 W., Duchesne County, Utah (unpublished data from Irvin Nielsen). 
Underlying the saline facies is a unit, about 460 to 700 feet (140 to $213 \mathrm{~m}$ ) thick, of predominantly claystone, subordinate limestone, and numerous thin tuffs, which is devoid of salts. The claystone and limestone unit is underlain by the Horse Bench Sandstone Bed (fig. 3).

The bedded salts at Duchesne can be traced on geophysical logs into other wells drilled in the area. Several beds of mixed halite and sodium carbonate salts are shown on the cross section in figure 3. The most prominent of these beds, unit 21 of Dyni and others (1985, fig. 4), ranges from 2 to 19 feet (0.6 to $5.8 \mathrm{~m}$ ) in thickness; it may not be present in the Mapco core hole 2. Other probable beds of sodium salts are also indicated on geophysical logs in figure 3. Bedded salts underlie an area of about 86 square miles (223 $\mathrm{km}^{2}$ ) just north of Duchesne (Dyni and others, 1985, fig. 1), but the area could be larger (fig. 4).

\section{BIRD'S-NEST BRINE FIELD}

During a brief, but strongly regressive phase of Lake Uinta during late Green River time, the Horse Bench Sandstone Bed was deposited over a wide area in the south-central part of Lake Uinta. The bed grades toward basin center to the north into open-lacustrine marly kerogenous rocks. During this regressive phase, the lake waters in the deeper part of the Uinta Basin became concentrated in salts, chiefly sodium bicarbonate with probable lesser amounts of sodium chloride. During early diagenesis, when the interstitial salty waters in the marly sediments were being expelled, nahcolite was precipitated within the marly sediments as scattered crystals, nodules, and crystalline aggregates. A few thin beds of nahcolite may have also been deposited. On the outcrop, the nahcolite-bearing sequence was informally named the "Bird's-nest zone," in reference to the numerous cavities, which resemble swallow nests, left by dissolution of the nahcolite nodules by surface waters (Cashion, 1967, p. 17). 
Percolating ground waters have dissolved the nahcolite forming an aquifer in the upper part of the Green River Formation in an area of about 250 square miles $\left(647 \mathrm{~km}^{2}\right)$ in parts of 14 townships (Twps. 8-11 S., Rgs. 22-25 W., Uinta County (fig. 6), about 30 miles south and east of Vernal, Utah (Lindskov and Kimball, 1984, figs. 13 and 20). The full extent of the aquifer has not yet been determined. In the southern part of the area in T. 10 S., R. 24 E., analyses from wells drilled on Federal lease tracts Ua and Ub indicate that the aquifer is slightly to moderately saline, ranging from 1,000 to 4,800 $\mathrm{mg} / \mathrm{l}$ of total dissolved solids (fig. 6). However, much higher salinities were encountered in the aquifer in two core holes drilled by the U.S. Geological Survey some 6 to 10 miles (10 to $16 \mathrm{~km}$ ) to the northwest in T. 9 S., Rs. 22 and 23 E. (figure 6). Chemical analyses of the brine in the aquifer in the two wells listed in table 1 are from Scott and Pantea (1982a, 1982b). 


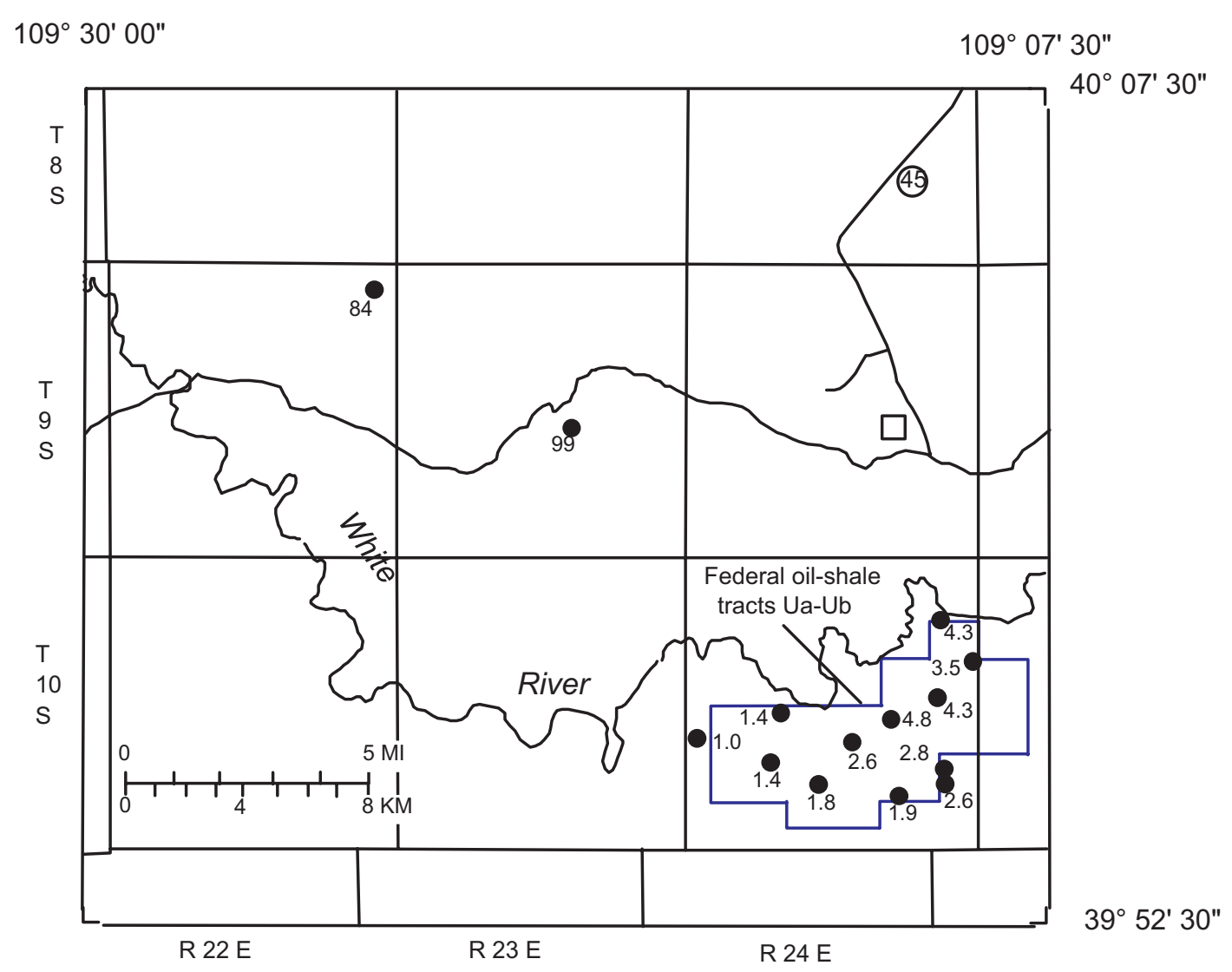

Figure 6. Locations of some wells drilled into the Bird's-nest aquifer near Bonanza, Utah. Numbers indicate total dissolved solids in grams/liter (from Lindskov and Kimball, 1984 and Scott and Pantea, 1982a,b). 
Table 1. Chemical analyses of the Bird's-nest aquifer in U.S. Geological Survey core holes Coyote Wash 1 and Red Wash 1.

\begin{tabular}{lll}
\hline & Coyote Wash 1 & Red Wash 1 \\
\hline Location & $\begin{array}{l}\text { SE1/4NE1/4 Sec. 22, } \\
\text { T.9 S., R.23 E. }\end{array}$ & $\begin{array}{l}\text { SE1/4NW1/4 Sec. 1, } \\
\text { T.9 S., R.22 E. }\end{array}$ \\
$\begin{array}{l}\text { Thickness of } \\
\text { aquifer(ft) }\end{array}$ & $65(19.8 \mathrm{~m})$ & $80(24.4 \mathrm{~m})$ \\
$\begin{array}{l}\text { Depth to top } \\
\text { of aquifer (ft) }\end{array}$ & $1,739(530 \mathrm{~m})$ & $2,021(616 \mathrm{~m})$ \\
$\begin{array}{l}\text { Sample depth (ft) } \\
\text { Rock matrix } \\
\text { Yield (gals/min) }\end{array}$ & $1,746(532 \mathrm{~m})$ & $2,021(616 \mathrm{~m})$ \\
& Oil shale & Oil shale \\
& $700(2,650 \mathrm{l} / \mathrm{min})$ & $700-900(2,650-3,400 \mathrm{l} / \mathrm{min})$ \\
\hline
\end{tabular}

Chemical composition (mg/l)

\begin{tabular}{lrr}
\hline $\mathrm{Cl}^{-}$ & 3,100 & 650 \\
$\mathrm{~F}^{-}$ & 26 & 450 \\
$\mathrm{SO}^{--}$ & 7,400 & 3,500 \\
$\left(\mathrm{HCO}^{-} / \mathrm{CO}^{--}\right)^{1}$ & $(13,130)$ & $(13,890)$ \\
$\mathrm{B}$ & 180 & 240 \\
$\mathrm{Na}^{+}$ & 34,000 & 41,000 \\
$\mathrm{~K}^{+}$ & 39 & 60 \\
$\mathrm{Ca}^{++}$ & 3 & $<1$ \\
$\mathrm{Mg}^{++}$ & 1 & 0.2 \\
$\mathrm{SiO}^{+}$ & $<2$ & $<2$ \\
Organic carbon, & & 60 \\
$\quad$ dissolved & $\mathrm{na}$ & 9.5 \\
$\mathrm{pH}$ & 9.5 & \\
Alkalinity & & 105,000 \\
$\quad$ as CaCO3) & 79,300 & 98,600
\end{tabular}

Other ions found in concentrations of less than $1 \mathrm{mg} / \mathrm{l}$ : As, Ba, Cr, Fe, Li, Mn, Hg, and Zn. See Scott and Pantea (1982a and 1982b) for additional analytical details.

The sum of $\mathrm{CO}_{3}+\mathrm{HCO} 3$ and total dissolved solids which were not determined in the original analyses were estimated by Scott R. Charlton, University of Colorado, by the USGS WATC computer program. 
Further exploration of the Bird's-nest brine field in the vicinity of the Coyote Wash and Red Wash core holes in T. 9 S., Rs. 22 and 23 E. and surrounding area (fig. 6) may reveal exploitable reserves of sodium carbonate brine. Dissolved components in amounts that might be troublesome in developing this resource include chloride, sulfate and fluoride.

\section{COLORADO NAHCOLITE DEPOSITS}

A large resource of nahcolite is commingled with oil shale in the Parachute Creek Member of the Green River Formation in the northern part of the Piceance Creek Basin in northwest Colorado. The geology of the deposit is well documented by numerous studies, although details of the stratigraphic distribution and grade of nahcolite in selected zones and beds need to be determined.

In the Piceance Creek Basin, the Green River Formation is divided, in ascending order, into the Anvil Points, Garden Gulch, and Parachute Creek Members and it is overlain by sandstone and siltstone of the Uinta Formation (fig. 7). Most of the significant deposits of oil shale and all of the sodium carbonate resources are found in the Parachute Creek Member.

In the deeper northern part of the Piceance Creek Basin, the Parachute Creek Member contains a saline facies which includes beds of nahcolite and halite, scattered crystals, nodules, and coarse-crystalline aggregates of nahcolite commingled with high-grade oil shale. Also included in the saline facies is dawsonite which occurs as microscopic crystals that compose part of the microcrystalline matrix of the oil shale.

The top of the nahcolite-bearing oil shale is a dissolution surface above which ground waters have dissolved nahcolite and halite forming a "leached zone" of vuggy brecciated oil shale sequence several hundred feet thick. The leached zone extends upward into lower part of the Mahogany oil-shale zone, a unit of high-grade oil shale traceable throughout the basin. The top of the leached zone is defined by the stratigraphically highest occurrence of solution breccia that marks the former presence of a bed of nahcolite or mixed halite and nahcolite (Dyni,1981, plates 1 and 2). This top can be considered to be the top of the original bedded saline facies in the Parachute Creek Member, although crystal cavities and vugs are found scattered through the upper part of the Parachute Creek Member above the Mahogany oil-shale zone (fig. 7). 

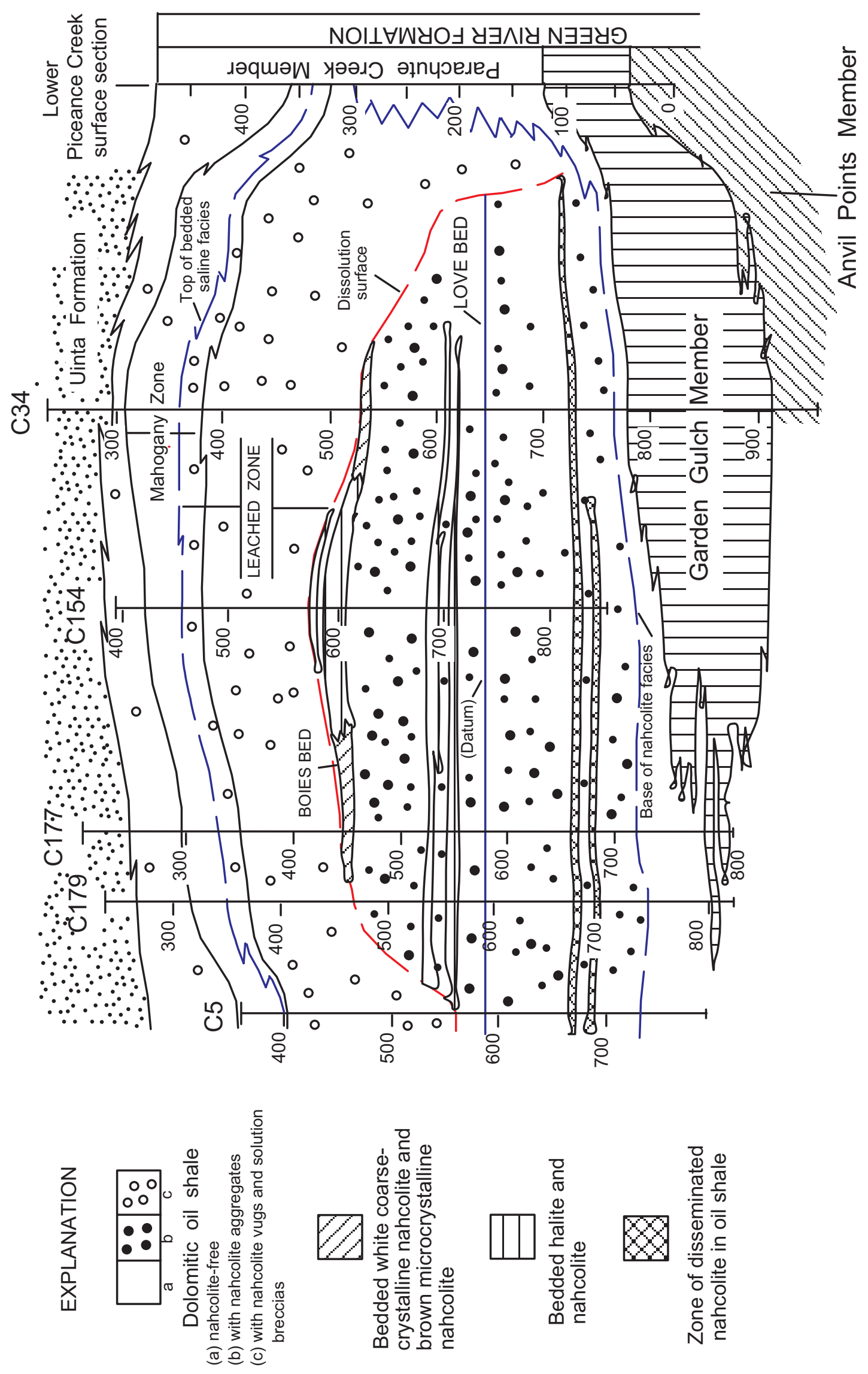

Figure 7. Generalized stratigraphic cross section of the nahcolite deposits in the Parachute Creek Member of the Green River Formation in the northern part of the Piceance Creek Basin, Colorado. Line of cross section is shown in fig. 8. Depths in meters. 


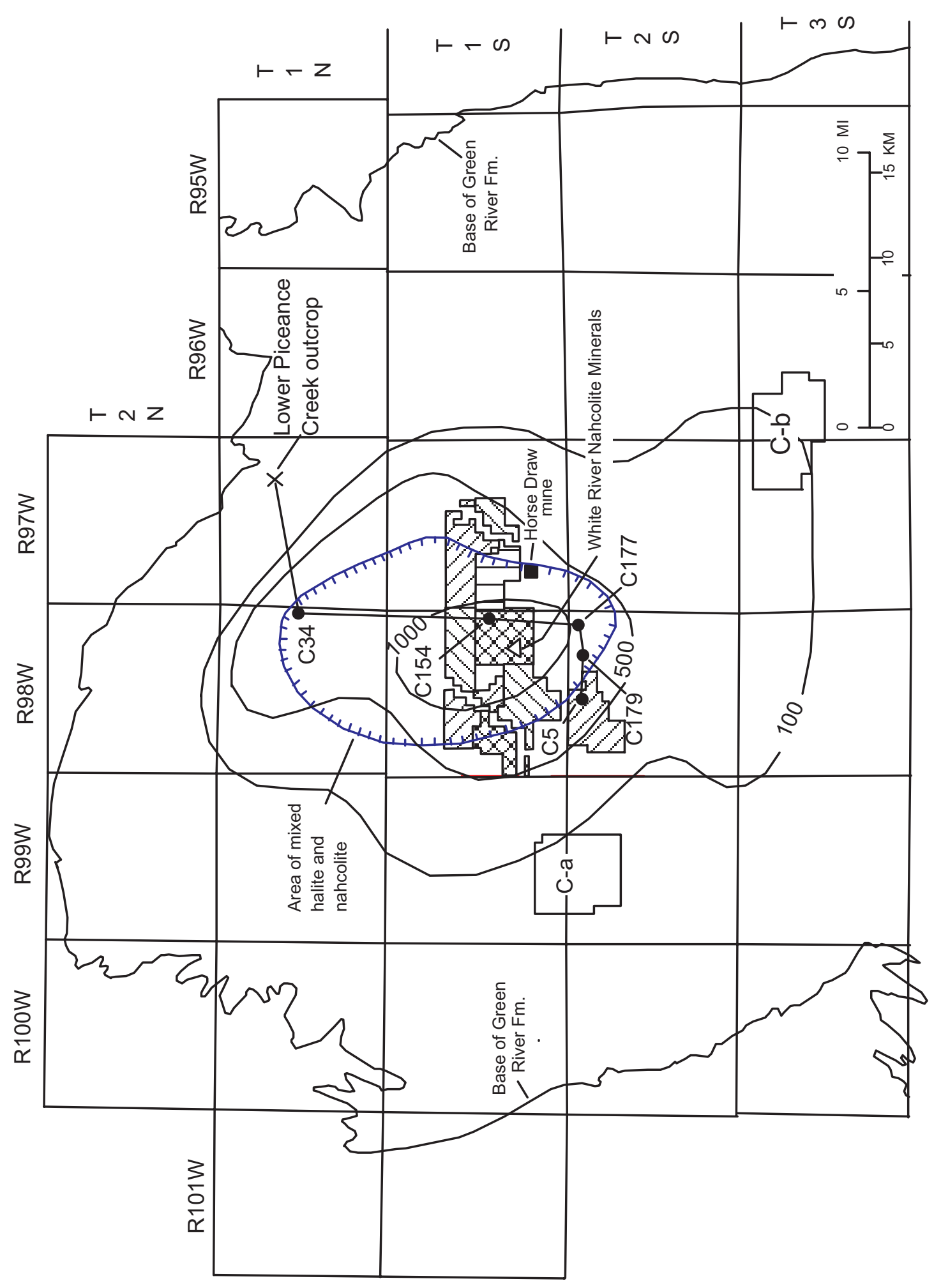

Figure 8. Thickness of nahcolite-bearing oil shale in the northern part of the Piceance Creek Basin. Thickness contours in feet. Patterned areas are active Federal sodium leases. C-a and C-b are inactive Federal oil-shale lease tracts. 
The maximum thickness of nahcolite-bearing oil shale is reached in Twps. $1 \mathrm{~N}$. to $2 \mathrm{~S}$., and Rs. 97-98 W. (fig. 8). Here, the dissolution surface lies at depths of about 1,400 to 1,900 feet (427 to $579 \mathrm{~m}$ ) below ground level (fig. 7). Below the dissolution surface, nahcolite occurs in three principal ways: (1) as coarse-crystalline aggregates and rosettes and fine-grained nodules scattered through oil shale, (2) as disseminated, closely to loosely packed crystals of nahcolite in oil shale that commonly form laterally continuous units, and (3) as beds of either microcrystalline light brown nahcolite, coarse-crystalline white nahcolite, or thin layers of brown microcrystalline nahcolite interbedded with coarse-crystalline halite. About 60 percent of the resource occurs as type 1 nahcolite, 25 percent as type 2 nahcolite, and 15 percent as type 3 nahcolite. The area of nahcolitebearing oil shale, where it is 100 or more feet thick occupies an area of about 257 square miles $\left(666 \mathrm{~km}^{2}\right)$ in the northern part of the Piceance Creek Basin (fig. 8). In ten core holes drilled in the central part of the evaporite deposit, the nahcolitic rocks range from about 550 to 1,100 feet (168 to $335 \mathrm{~m}$ ) in thickness. The nahcolite resource in the basin was estimated at 32 billion short tons (29 billion mt) by Dyni (1974a,1974b) and 29 billion tons (26 billion mt) by Beard, Tait, and Smith (1974). Details of the economic geology of the Colorado nahcolite deposits have been reported by Cole, Daub, and Weichman, (1982); Cole and Daub (1983); Cole, Daub, and Weston (1995); Nielsen (1995), and others.

In 1970-72, Shell Oil Company experimented with warm water and steam injection for recovery of shale oil from nahcolite-bearing oil shale on a 10-acre site in the $\mathrm{W}^{1 / 2} \mathrm{~T}$. 1 S., R. 97 W., Rio Blanco County, Colo. In addition to oil, Ireson (1990) reported that large amounts of sodium carbonate were co-produced with the oil (fig. 9).

In 1990, the White River Nahcolite Minerals Company, a subsidiary of North American Chemical Company, began solution mining the Boies nahcolite bed on a 8,222-acre (3,327 hectare) Federal sodium lease tract located in T. 1 S., R. 98 W., Rio Blanco County, Colorado (fig. 8). The mining method involves drilling a vertical hole to within several hundred feet above the bed, turning the hole so that it enters the bed at a slight angle, then drilling the hole horizontally along the base of the bed. Hot water injected into the bed dissolves the nahcolite and forms a horizontal cavity. Sodium carbonate brine is recovered from another vertical hole drilled into the cavity some hundreds of feet from the injection hole. Where mined, the Boies bed is about 25 feet $(7.6 \mathrm{~m})$ thick and lies at a depth of 2,000 (610 m) feet (Day, 1994). 
35

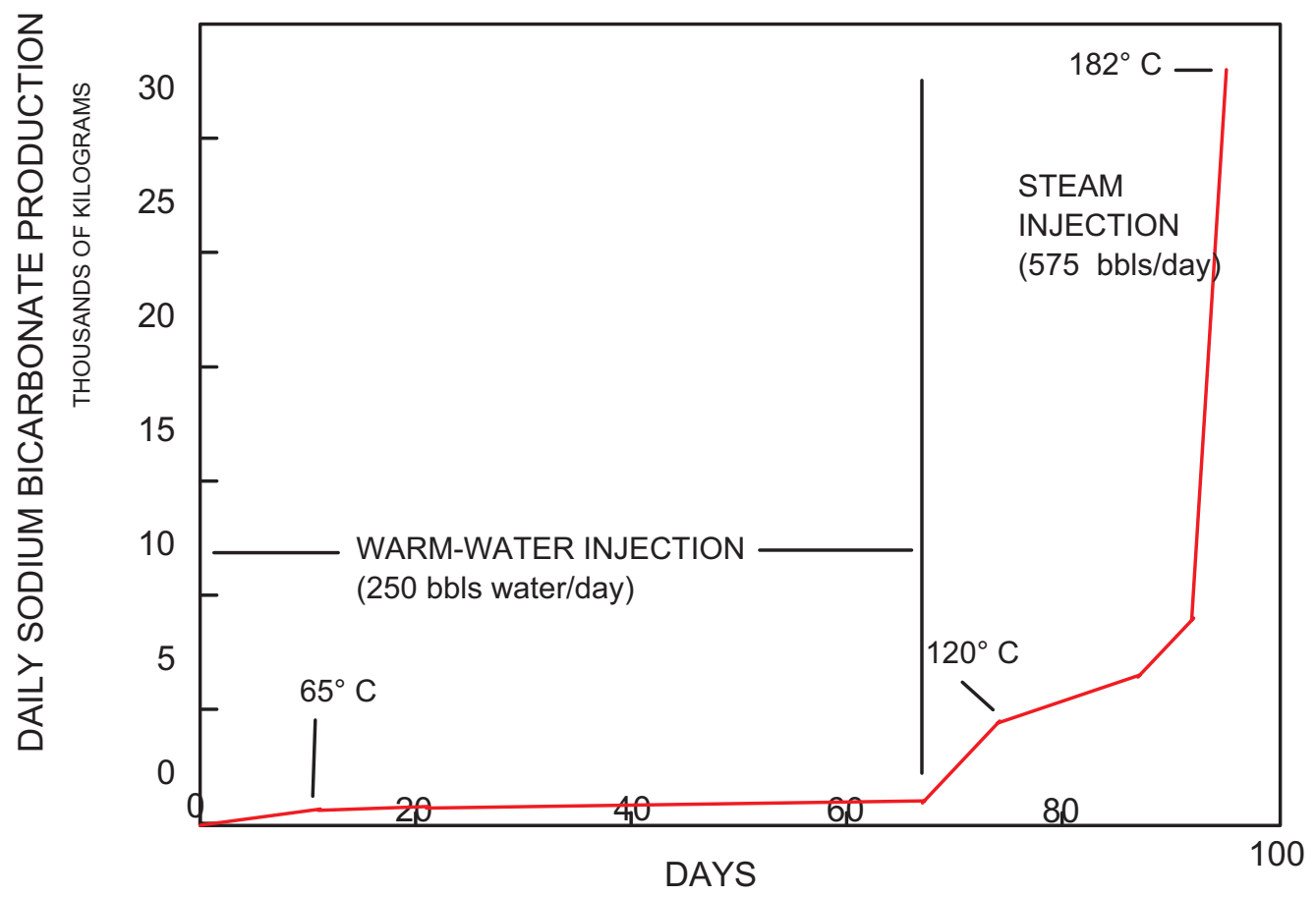

Figure 9. Daily production of sodium bicarbonate from Shell in situ shale-oil recovery experiment in the Piceance Creek Basin (from Ireson, 1990). 
Currently, eight Federal sodium leases have been issued on about 16,900 acres $(6,839$ hectares) in the basin (fig. 8). Over the past few years, another company has been drilling exploratory core holes in the basin for possible leasing of sodium minerals.

In addition to the Boies bed (L-5A), several other nahcolite beds in the Piceance Creek Basin may be economical to solution mine including the L-4D (Love bed) and R-5C, R5E and R-5G beds (Dyni, 1981, plates 1 and 2).

Solution mining nahcolite in the Piceance Creek Basin presents some unusual problems. Because the Boies bed is close to the dissolution surface (fig. 7), a breakthrough into the overlying water-bearing leached zone could be detrimental to solution mining in the bed. Furthermore, the Boies bed grades laterally into mixed halite and nahcolite toward the basin chemical depocenter which could contaminate mining solutions with sodium chloride. The Boies bed as shown by Dyni (1981, plates 1 and 2) actually consists of two beds, the lower one being thinner, but also containing halite. Because oil shale cannot be mined or damaged under current sodium leasing regulations, the major part of the nahcolite resource, which occurs as crystalline aggregates scattered through oil shale, will be difficult to mine for soda ash alone. Solution mining of nahcolite beds in the basin may render parts of the overlying oil shale unsuitable for future in situ or underground mining.

\section{EDEN-FARSON BRINE FIELD}

H.B. Lindeman (1954) first called attention to amber sodium carbonate brine found at depths of 400 to 600 feet (122 to $183 \mathrm{~m}$ ) in the Green River Basin near the communities of Eden and Farson, about 30 miles (48 km) north of Rock Springs, Wyoming. The discovery of brine was made by the John Hay water well drilled in 1938 in SE $1 / 4$ sec. 4, T. 23 N, R. 106 W., Sweetwater County, Wyoming. Subsequent exploratory drilling (fig. 10) identified many drill holes that encountered black sodium carbonate brine (Dana and Smith 1973, 1976). Analyses of brine from four wells by Phillips (1978, table 2) revealed as much as 4-6 weight percent sodium carbonate-bicarbonate and as much as 5.8 weight percent of water-soluble humic and fulvic acids. Even larger amounts of these components were reported from other wells by Dana and Smith $(1973,1976)$. 


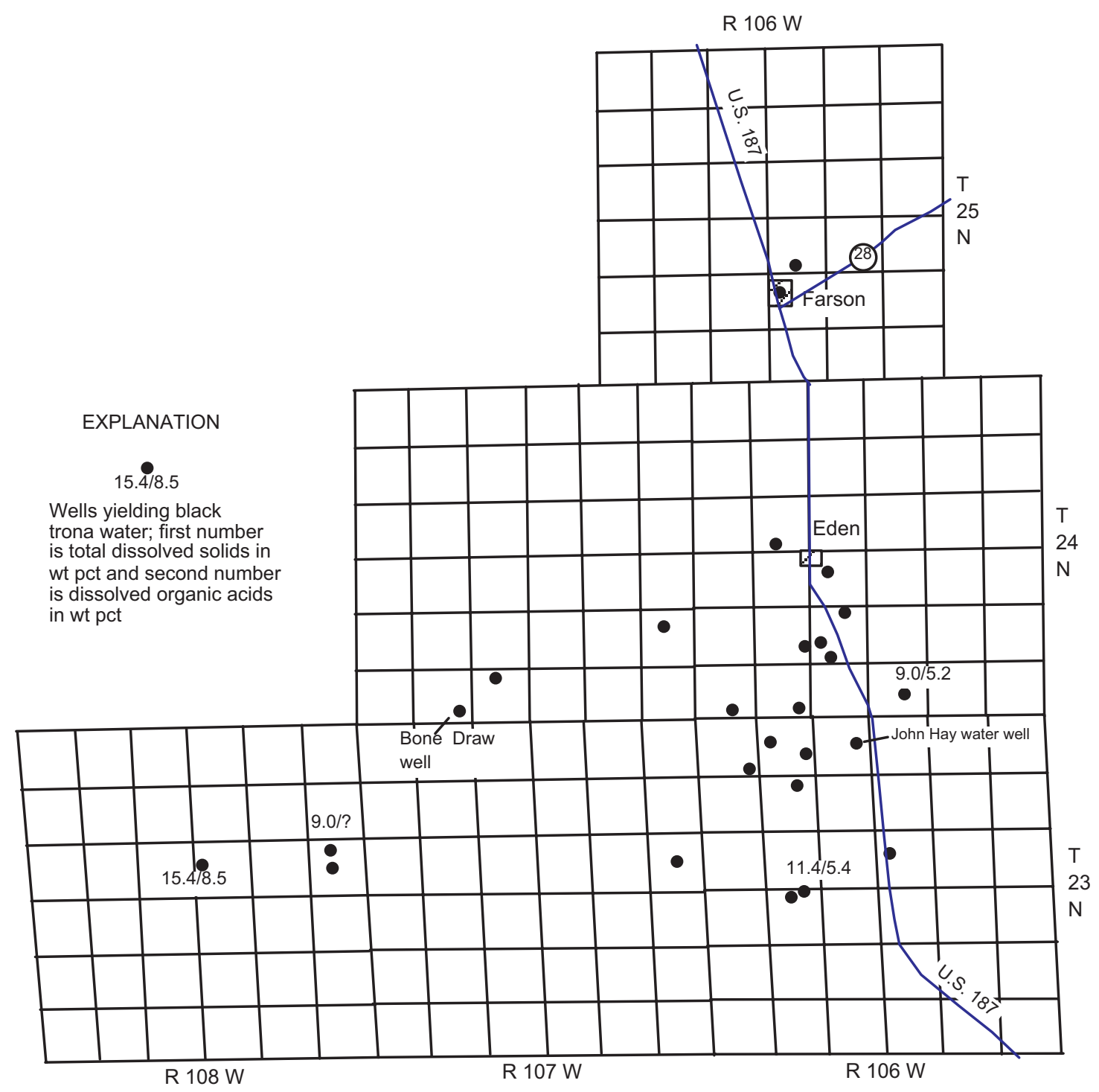

Figure 10. Map showing locations of wells containing sodium carbonate brine and dissolved organic matter in the Eden-Farson brine field in the northeastern part of the Green River Basin, Sweetwater County, Wyoming (from Dana and Smith, 1976, and Phillips, 1978). 
In 1992, a shallow well was drilled for water by the U.S. Bureau of Reclamation in Bone Draw in the NE $1 / 4 \mathrm{SE}^{1 / 4}$ sec. 32, T. 24 N., R. $107 \mathrm{~W}$., about 6 miles (10 km) southwest of Eden. The well encountered an artesian flow of black sodium carbonate brine at 460 feet $(140 \mathrm{~m})$. The well flowed an estimated 29,000 barrels (4,611 cu. meters) of brine in two weeks before it could be sealed. A sample of the brine was analyzed by the Water Resources Division of the U.S. Geological Survey, Denver, Colorado, and the results are given in table 2 .

Table 2. - Chemical analysis of brine from the U.S. Bureau of Reclamation Bone Draw well 1.

\begin{tabular}{lrl}
\hline Dissolved species: & 13,080 & $\mathrm{mg} / \mathrm{l}$ \\
Carbonate & 8,650 & $\mathrm{mg} / \mathrm{l}$ \\
Bicarbonate & 150 & $\mathrm{mg} / \mathrm{l}$ \\
Chloride & 78 & $\mathrm{mg} / \mathrm{l}$ \\
Fluoride & 0.8 & $\mathrm{mg} / \mathrm{l}$ \\
Sulfate & 22,500 & $\mathrm{mg} / \mathrm{l}$ \\
Sodium & 58 & $\mathrm{mg} / \mathrm{l}$ \\
Potassium & 3 & $\mathrm{mg} / \mathrm{l}$ \\
Calcium & 1 & $\mathrm{mg} / \mathrm{l}$ \\
Magnesium & 20 & $\mu \mathrm{g} / \mathrm{l}$ \\
Lithium & 982 & $\mathrm{mg} / \mathrm{l}$ \\
Dissolved organic carbon & 50,500 & $\mathrm{mg} / \mathrm{l}$ \\
Alkalinity, as CaCO 3 & 9.9 & \\
pH, lab & 49,900 & $\mu / \mathrm{Siemens}$ \\
Conductance, lab & & \\
\end{tabular}

The black sodium carbonate brine is found in oil shale of the Wilkins Peak Member of the Green River Formation. The brine appears to be in several discontinous permeable zones because water flows and concentrations of dissolved solids, (including watersoluble organic matter) are highly variable between wells (figure 10). 
Dana and Smith (1976) concluded from examination of drill core from one bore hole that the brine is confined to one or more bedding planes in otherwise impermeable oil shale of the Wilkins Peak Member. These authors noted that a number of the wells in the brine field are artesian and suggested that the brine in the aquifer is pressurized by lithostatic, rather than hydrostatic or gas, pressure. Because of the unusual type of aquifer, the size of the brine field and the composition of the brine cannot be easily determined. According to Dana and Smith (1976) the stratigraphic interval in which the brine is found lies between 67 and 93 feet (19 and $28 \mathrm{~m}$ ) below the top of the Wilkins Peak Member. In the trona district to the southwest, this would place the aquifer just above the highest bed (25) of trona in the member.

The origin of the brine cannot be directly linked to dissolution of sodium carbonate salts inasmuch as solution breccias or cavities were not found in the oil shale enclosing the suspected brine aquifer (Dana and Smith, 1976). However, Culbertson (1966, p. B160) suggested that the source of the sodium carbonate in the Eden area was from dissolution of shortite, which is a common salt in the Wilkins Peak Member, rather than from bedded trona. Although salt cavities are absent in the core studied by Dana and Smith (1976), the brine may have formed further south in the basin and migrated updip along bedding and fracture planes northward toward the Eden area.

The brine has economic potential as a source of soda ash and organic acids. The precipitated organic acids yield as much as 73.3 percent oil upon destructive distillation. The organic acids may also find specialized uses, such as a soil conditioner (R.J. Hite, 1996, personal comm.). Dana and Smith (1976, p. 12) reported a well capable of flowing at a rate of 6,800-6,900 barrels (1,081-1,097 cu. meters) of brine per day, which could yield 62 tons (56 mt) of soda ash and 130 tons $(118 \mathrm{mt})$ of organic acids per day.

Several companies have examined the brine for possible exploitation, but none to date have pursued development of the resource. The Eden-Farson brine field may be mineable on a small scale, especially if the organic acids find specialized uses that may command a high unit price. Also, the occurrence of sodium carbonate brine elsewhere in the Green River Basin should not be overlooked. 


\section{WYOMING TRONA DEPOSITS}

The world's largest known resource of natural sodium carbonate is found in bedded trona in the Green River Formation in the Green River Basin in Sweetwater County, southwest Wyoming. The formation is divided in ascending order into the Tipton Shale, Wilkins Peak Member, and the Laney Shale. The trona resource lies wholly within the Wilkins Peak Member. The Wilkins Peak ranges from about 600 to 1,350 feet (183 to $411 \mathrm{~m}$ ) in thickness and consists of marlstone, oil shale, trona, siltstone, mudstone, and numerous laterally persistent thin layers of tuff.

As many as 42 beds of trona were noted by Culbertson (1966). He numbered the thickest and economically most important of these beds from 1 to 25 in ascending order (figs. 11 and 12). The trona beds are nearly flat lying. Dips are commonly about $1^{\circ}$ or less. Faults are uncommon; however, several strike-slip shear zones have been recently mapped on the surface on the east side of the basin by Gordon Marlatt, University of Wyoming graduate student (personal comm, 1996). Some trona beds grade laterally into mixed halite and trona toward the depocenter in the southern part of the basin. In some beds in the lower part of the evaporite sequence, nahcolite is abundant. I have noted from X-ray diffraction studies of mine and core samples that as the depositional center of mixed halite and trona of bed 17 is approached in the southern part of the basin, nahcolite, wegscheiderite, northupite, and possibly shortite become locally abundant, as well as quartz. The occurrence of these additional minerals may be important in room-and-pillar mining because they may influence the processing of trona as well as impart different physical properties to the mined trona.

The generalized lithology of the Wilkins Peak Member in the Union Pacific Railroad, El Paso core hole 44-3, in the southern part of the basin is shown in figure 13. Many of the lower trona beds are shown on the log. Two stratigraphic cross sections showing the distribution of the trona beds in different parts of the basin are shown in figures 11 and 12. 


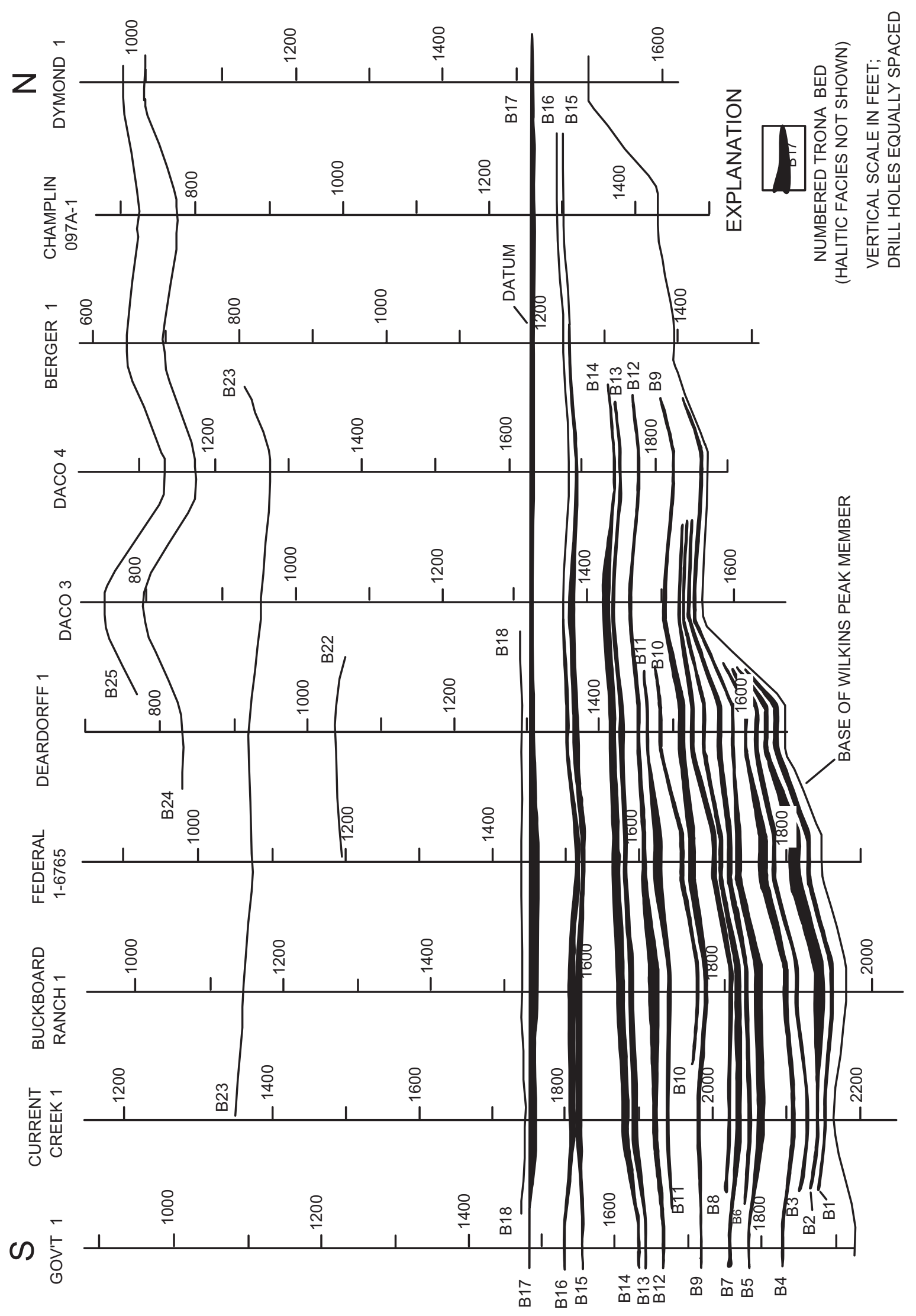

Figure 11. South-north stratigraphic cross section of the trona deposits in the Green River Basin, Wyoming. Line of section shown in fig. 15. 


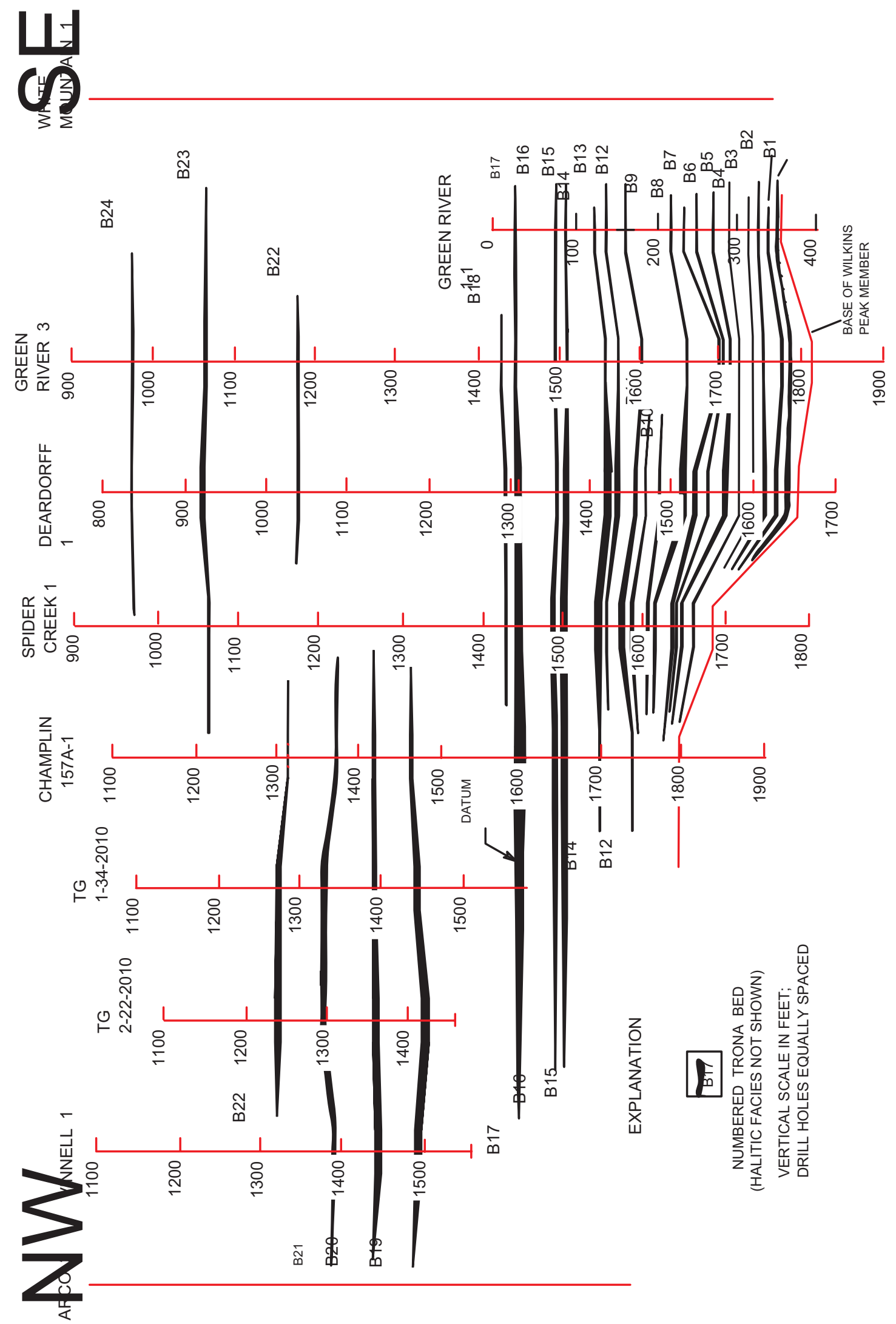

Figure 12. Northwest-southeast stratigraphic cross section of the trona deposits in the Green River Basin, Wyoming. Line of section shown in fig. 15. 


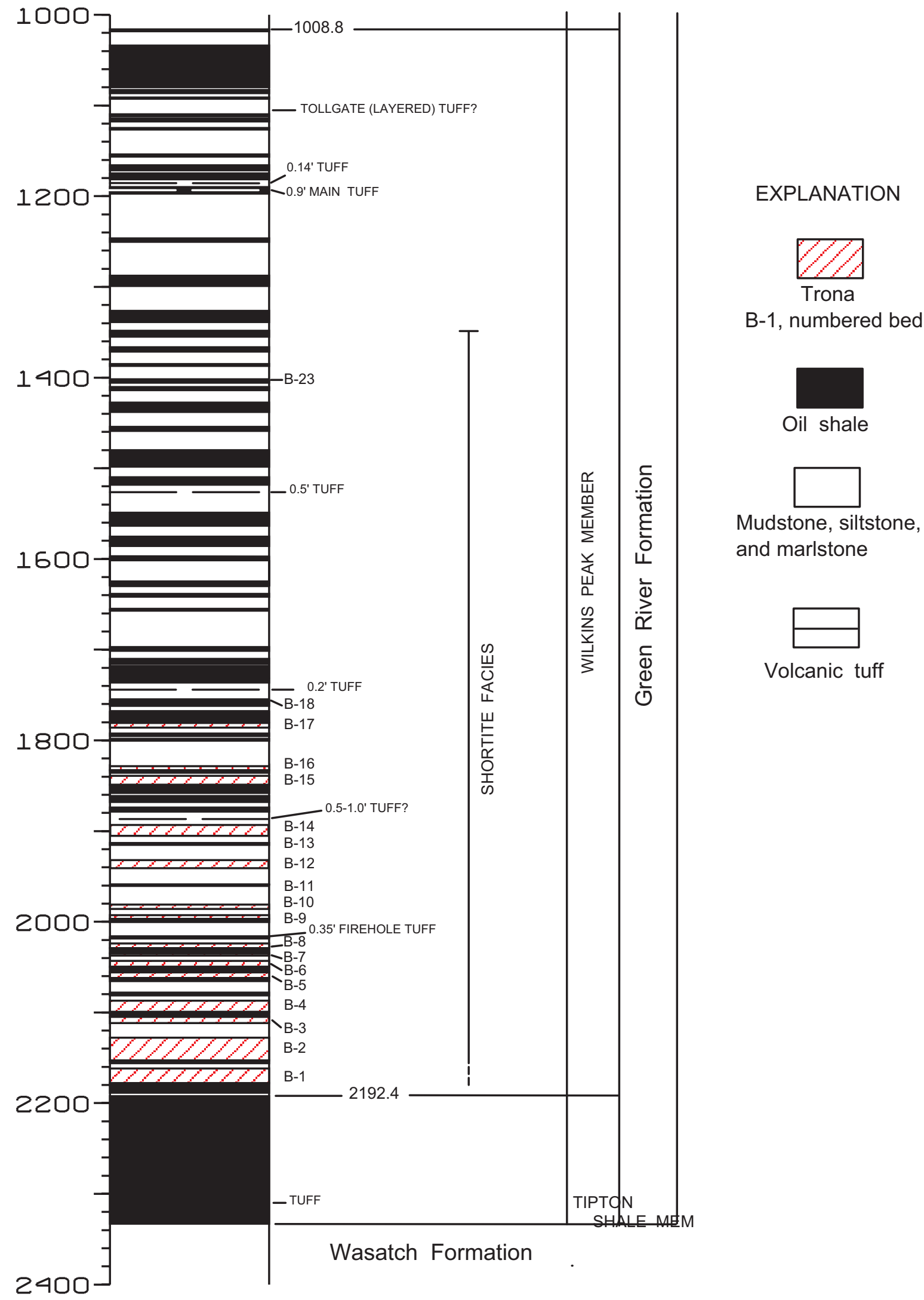

Figure 13. Generalized lithologic log of the Union Pacific Railroad, El Paso 44-3 core hole in the $\mathrm{SE}^{1} / 4 \mathrm{SE}^{1} / 4$ sec. 3, T.15 N., R.109 W., Sweetwater County, Wyoming (modified from Trudell, 1975). Core hole location shown in fig. 15. 
The trona beds are remarkable for their purity. Sulfate minerals are essentially absent, and other than halite, the chief impurities are marlstone stringers and vertical seams of mudstone. Chemical analyses of several trona beds are given by Wiig, Grundy, and Dyni (1995, table 1). Currently, FMC, General Chemical, and Solvay Minerals mine trona bed 17, TG Soda Ash mines bed 20, and Oriental Chemicals mines beds 24 and 25 (Leigh, 1991).

Trona bed 17 is one of the most important trona beds in the district. The bed, where it is more than 4 feet $(1.2 \mathrm{~m})$ thick, underlies about 775 square miles $\left(2,007 \mathrm{~km}^{2}\right)$ and ranges from 4 to 17 feet (1.2 to $5.2 \mathrm{~m}$ ) in thickness (figure 14). Southward in the basin, the trona grades laterally into mixed halite and trona.

Twenty-two of the 25 numbered beds are estimated to contain 127 billion tons (115 billion $\mathrm{mt}$ ) of trona ore, or 76 billion tons ( 69 billion $\mathrm{mt}$ ) of trona in beds containing less than 2 percent halite. These 22 beds, where they are 4 or more feet (1.2 or more meters) thick, underlie areas ranging from 50 to more than 775 square miles (129 to more than $2,007 \mathrm{~km}^{2}$ ) at depths of 650 to 3,000 feet (198 to $914 \mathrm{~m}$ ) below the surface (Wiig, Grundy, and Dyni, 1995). Trona contains 70.3 weight percent sodium carbonate; it takes about 2 tons of trona ore to produce 1 ton of soda ash.

Additional resources of sodium carbonate in the Green River Formation include shortite, which occurs in abundant crystals, pods, and veinlets scattered through marly lacustrine strata interbedded with the trona. Less commonly, some shortite may be in bedded layers a few centimeters thick. Shortite contains 34.6 percent sodium carbonate by weight.

A visual estimate of shortite in drill core from the John Hay core hole 1 in the SE $1 / 4 \mathrm{NW}^{1 / 4}$ sec. 2, T. 18 N., R. 110 W., Sweetwater County was made by Fahey and Mrose (1962, figure 7). Shortite averaged about 11 percent for a sequence 550 feet $(168 \mathrm{~m})$ thick between the depths of 1,250 and 1,800 feet (381 and $579 \mathrm{~m}$ ), and 16.7 percent for a 230foot-thick $(70 \mathrm{~m}$ ) sequence between the depths of 1,330 and 1,560 feet (405 and $475 \mathrm{~m}$ ). Assuming a similar grade for a one square mile $1.6 \mathrm{~km}^{2}$ ) block around this bore hole, as much as 203 million tons (184 million $\mathrm{mt}$ ) of shortite, or 70 million tons (64 million $\mathrm{mt}$ ) of sodium carbonate, per square mile is indicated-a substantial resource. 


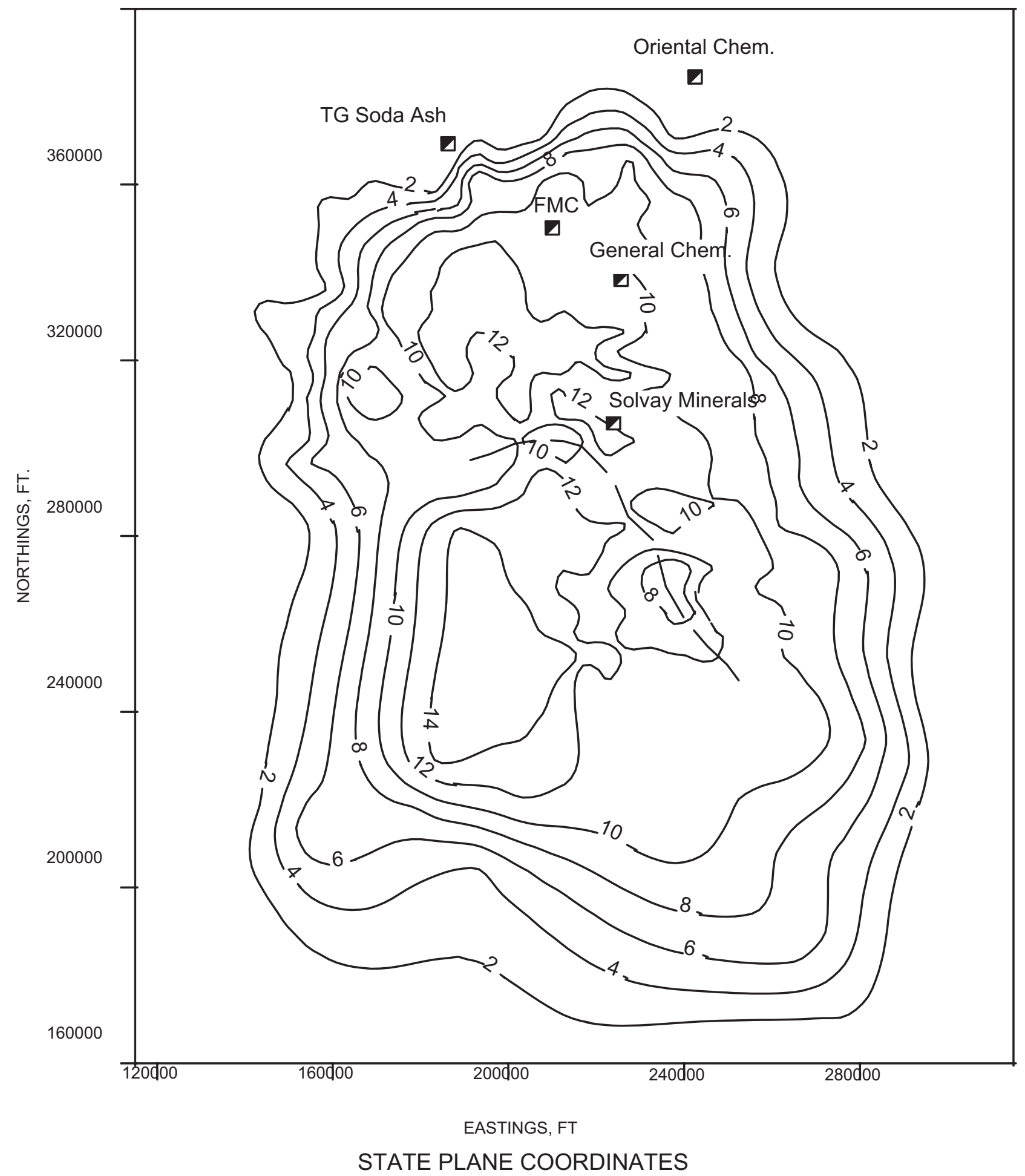

Figure 14. Isopach map, in feet, of trona bed 17. Dotted line indicates a trough of thinned trona in the central part of the bed (modified from Wiig, Grundy, and Dyni, 1995). 
Because of its mode of occurrence, shortite (or sodium carbonate) would be difficult to mine separately, although some sodium carbonate from the mineral might be extractable by solution mining.

The Wyoming trona district currently produces about 9 million tons ( 8.2 million $\mathrm{mt}$ ) of refined soda ash annually from five underground mines that extract a total of about 18 million tons (16.3 million mt) of trona ore (personal comm., Ray Harris, 1996). See papers by Wiig, Grundy, and Dyni (1995), Burnside and Culbertson (1979), and Brown (1995) for additional resource, production, and mining details.

Mining is by vertical shaft using room-and-pillar, short- and long-wall techniques. At three mines, additional sodium carbonate is recovered from waste waters from the processing plant which are used to slurry tailings to abandoned parts of the mines. These waters dissolve additional trona from the pillars, then are pumped back to the surface to recover the sodium carbonate. The technique has proven to be economical and will probably be employed by the remaining mines in the district.

Earlier attempts to solution mine trona from vertically drilled holes have been unsuccessful. However, solution mining using horizontally drilled holes as used in the Piceance Creek Basin, Colorado, has not yet been attempted, but the method will probably be tested soon in the Wyoming trona district. The method may be especially useful in the southern part of the basin where the trona beds are thicker and lie at greater depths than those being mined today.

Solution mining appears to offer major advantages over room-and-pillar techniques. Drilling injection and production wells should cost less than the cost of sinking shafts and opening underground workings. Solution mining will provide safer operating conditions because underground miners will not be needed. Room-and-pillar mining of trona beds in the deeper part of the basin, which would require larger pillars for safety and lower the recovery of trona ore, should pose no serious problems for solution mining. Concurrent solution mining of multiple trona beds should also be feasible. 
Approval of mining plans should assure trona-land owners that important trona beds are not made unmineable by multi-bed solution mining, land subsidence is controlled, potential oil and gas production is not impaired, and significant parts of the trona resource are not lost by high-grading the thicker and purer beds of trona in the lower part of the deposit.

Ownership of the trona lands is divided between the Federal Government (55.7 percent), Union Pacific Resources as part of a railroad land grant (38.1 percent), and the state of Wyoming (6.2 percent). Figure 15 shows the boundary of the Federal known sodium leasing area, the five trona mine permit areas, and two lines of stratigraphic sections. A good summary of the soda ash industry was published recently by Kostick (1995).

The trona resources are summarized in figure 16. Trona bed 2 underlies 439 square miles $\left(1,137 \mathrm{~km}^{2}\right)$ where it is 4 or more feet (1.2 or more meters) thick and contains the largest resource of trona of any bed estimated at 11.6 billion tons ( 10.5 billion $\mathrm{mt}$ ) of which 97 percent of the bed is essentially halite-free. Trona bed 17, where it is 4 or more feet thick, underlies about 775 square miles $\left(2,007 \mathrm{~km}^{2}\right)$ and contains almost as much trona -11.5 billion tons ( 10.4 billion $\mathrm{mt}$ ), but only 66 percent contains little or no halite (Wiig, Grundy, and Dyni, 1995, table 9). Note that the trona beds above bed 18 and below bed 5 are free, or nearly free, of halite.

\section{SUMMARY}

The geology and economic potential of five occurrences of sodium carbonate deposits in the Eocene Green River Formation are briefly described. The two largest of these are the deposits of bedded trona and disseminated shortite in southwest Wyoming and bedded and nonbedded nahcolite and fine-grained disseminated dawsonite commingled with high-grade oil shale in northwest Colorado.

Other lesser known deposits that may have economic potential include bedded eitelite near Duchesne, Utah, and two sodium carbonate brines, one in the eastern Uinta Basin, Utah, and the other near Farson and Eden in the northeastern part of the Green River Basin, Wyoming. 


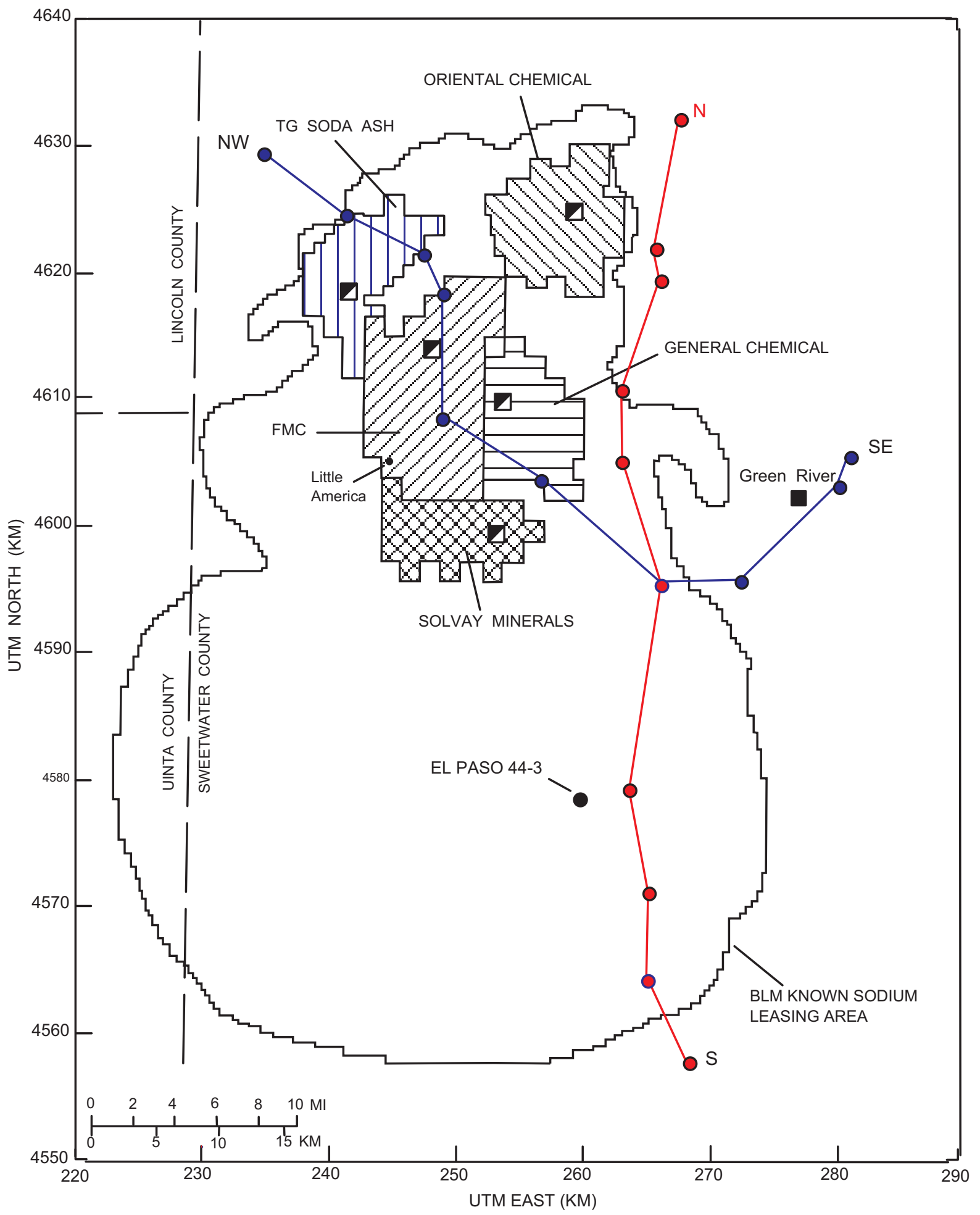

Figure 15. Map showing the Known Sodium Leasing Area established by the U.S. Bureau of Land Management, Wyoming state trona mine permit areas, and lines of stratigraphic sections shown in figs. 11 and 12. 


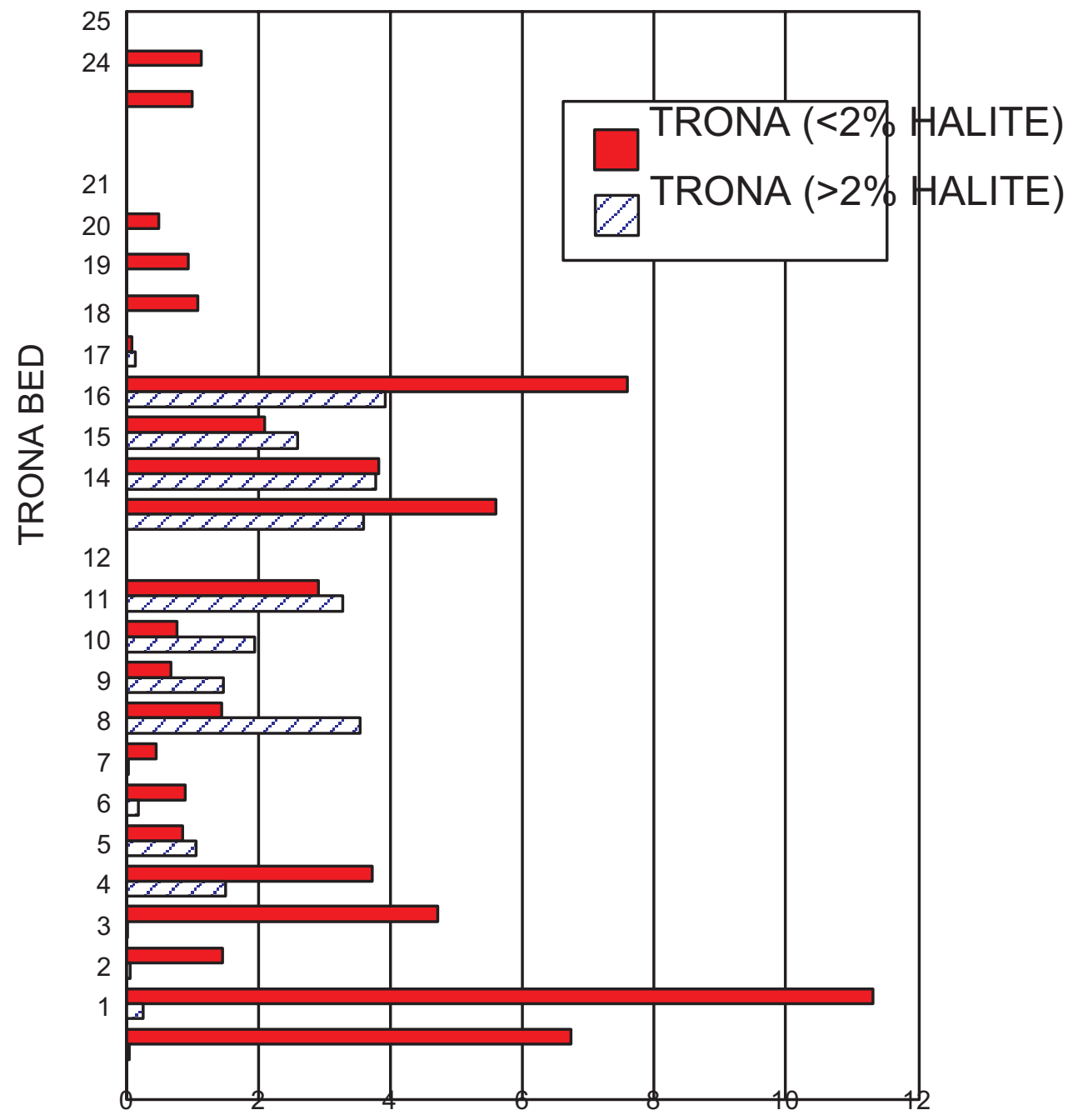

(BILLIONS OF SHORT TONS)

Figure 16. Trona resource estimates, in short tons, for 22 numbered beds of trona in the Wyoming trona district. Data are based on beds that are 4, or more, feet thick. Note that trona beds 1-4 and 19-25 are halite-free or nearly halite-free. 
The sodium carbonate resources in the Green River Formation will continue to provide most of the soda ash to domestic markets as well as acquire an increasing share in foreign markets for the foreseeable future. The technical success of solution mining bedded nahcolite in Colorado suggests that a similar operation would be successful in the Wyoming trona district. Solution mining beds of trona through horizontally drilled holes, may substantially lower mining costs and improve mine safety. Potential environmental problems such as disposal of plant tailings, waste waters, and stack-gas effluents including carbon dioxide could be reduced by solution mining methods.

\section{REFERENCES}

Beard, T.N., Tait, D.B., and Smith, J.W., 1974, Nahcolite and dawsonite resources in the Green River Formation, Piceance Creek Basin, Colorado in Murray, D.K., Energy resources of the Piceance Creek Basin, Colorado, 25th field conference: Rocky Mountain Assoc. Geologists, p. 101-122.

Bradley, W.H., 1931, Origin and microfossils of the oil shale of the Green River Formation of Colorado and Utah: U.S. Geological Survey Prof. Paper 168, 58 p.

Brown, N.A., 1995, Union Pacific instrumental in developing Wyoming trona: Mining Engineering, v. 47, p. 135-141.

Bryant, Bruce, Naeser, C.W., Marvin, R.F., and Mehnert, H.H., 1989, Upper Cretaceous and Paleogene sedimentary rocks and isotopic ages of Paleogene tuffs, Uinta Basin, Utah: U.S. Geological Survey Bulletin 1787-J, p. J1-J22.

Burnside, M.J., and Culbertson, W.C., 1979, Trona deposits in the Green River Basin, Sweetwater, Uinta and Lincoln Counties, Wyoming: U.S. Geological Survey openfile rept. 79-737, $10 \mathrm{p}$.

Cashion, W.B., 1967, Geology and fuel resources of the Green River Formation, southeastern Uinta Basin, Utah and Colorado: U.S. Geological Survey Prof. Paper $548,48 \mathrm{p}$.

Cole, R.D., and Daub, G.J., 1983, Microcrystalline nahcolite on the 1840 level, Horse Draw mine, Piceance Creek Basin, Colorado in Gary, J.H., [ed.] Sixteenth Oil Shale Symposium Proceedings: Colorado Sch. Mines Press, p. 99-112.

Cole, R.D., Daub, G.J., and Weichman, B.E., 1982, Geology of the Horse Draw nahcolite and oil-shale mine, Piceance Creek Basin, Colorado in Gary, J.H., Fifteenth Oil Shale Symposium Proceedings: Colorado Sch. Mines Press, p. 15-28. 
Cole, R.D., Daub, G.J., and Weston, L.K., 1995, Review of geology, mineral resources, and ground-water hydrology of Green River Formation, north-central Piceance Creek Basin, Colorado in The Green River Formation in Piceance Creek and Eastern Uinta Basins: Grand Junction Geological Soc., p. 63-81.

Culbertson, W.C., 1966, Trona in the Wilkins Peak Member of the Green River Formation, southwestern Wyoming in Geological Research 1966: U.S. Geol. Survey Prof. Paper 550-B, p. B159-B164.

Dana, G.F., and Smith, J.W., 1973, Black trona water, Green River Basin in Wyoming Geological Association Guidebook, 25th Annual Field Conference, p. 153-156.

Dana, G.F., and Smith, J.W., 1976, Nature of black trona water occurrence, northern Green River Basin: Wyoming Geological Assoc. Earth Science Bull., v. 9, p. 9-15.

Dane, C.H., 1955, Stratigraphic and facies relationships of the upper part of the Green River Formation and the lower part of the Uinta Formation in Duchesne, Uintah, and Wasatch Counties, Utah: U.S. Geological Suvey Chart OC 52.

Day, Roger, 1994, White River nahcolite solution mine [preprint]: Soc. Mining, Metall., and Exploration Annual Meeting, Albuquerque, New Mexico., 4 p.

Dyni, J.R., 1974a, Stratigraphy and nahcolite resources of the saline facies of the Green River Formation in northwest Colorado in Murray, D.K., Energy resources of the Piceance Creek Basin, Colorado, 25th field conference: Rocky Mountain Assoc. Geologists, p. 111-122.

Dyni, J.R., 1974b, Stratigraphy and nahcolite resources of the saline facies of the Green River Formation, Rio Blanco County Colorado: U.S. Geol. Surv. Open-File Rept. 746-56, $28 \mathrm{p}$.

Dyni, J.R., 1981, Geology of the nahcolite deposits and associated oil shales of the Green River Formation in the Piceance Creek Basin, Colorado: University of Colorado PhD thesis, $144 \mathrm{p}$.

Dyni, J.R., Milton, Charles, and Cashion, W.B., Jr., 1985, The saline facies of the upper part of the Green River Formation near Duchesne, Utah in Geology and Energy Resources, Uinta Basin of Utah: Utah Geol. Assoc., Salt Lake City, p. 51-80.

Erickson, M.P., 1952, New locality of shortite: American Mineralogist, v. 37, p. 342344.

Fahey, J.J., and Mrose, M.E., 1962, Saline minerals of the Green River Formation with a section on X-ray powder data for saline minerals of the Green River Formation: U.S. Geological Survey Prof. Paper 405, 50 p. 
Ireson, A.T., 1990, Review of the soluble salt process for in situ recovery of hydrocarbons from oil shale with emphasis on leaching [of nahcolite] and possible beneficiation in Gary, J.H., [ed.], Twenty-third Oil Shale Symposium Proceedings: Colorado Sch. Mines Press, Golden, p. 152-155.

Kostick, D.S., 1995, Soda Ash, Annual Review_1995: U.S. Geological Survey Mineral Industry Surveys, $10 \mathrm{p}$.

Leigh, R.T., 1991, Wyoming trona: an overview of the geology and economic utilization in Wyoming Geological Assoc. guidebook, 42nd field conference, p. 103-120.

Lindeman, H.B., 1954, Sodium carbonate brine and trona deposits in Sweetwater County, Wyoming: U.S. Geological Survey Circular 235, 10 p.

Lindskov, K.L., and Kimball, B.A., 1984, Water resources and potential hydrologic effects of oil-shale development in the southeastern Uinta Basin, Utah and Colorado: U.S. Geological Survey Professional Paper 1307, 32 p.

Milton, Charles, 1957, Authigenic minerals of the Green River Formation of the Uinta Basin, Utah in Guidebook to the Geology of the Uinta Basin, 8th Ann. Field Conference: Intermountain Assoc. Petrol. Geologists, p. 136-143.

Milton, Charles, Axelrod, J.M., and Grimaldi, F.S., 1954, (Abs.) New minerals reedmergnerite $(\mathrm{Na} 2 \mathrm{O} . \mathrm{B} 2 \mathrm{O} 3.6 \mathrm{SiO} 2)$ and eitelite $(\mathrm{Na} 2 \mathrm{O} . \mathrm{MgO} . \mathrm{CO} 2)$ associated with leucosphenite, shortite, searlesite, and crocidolite in the Green River Formation, Utah: Geological Society of America Bull. , v. 65, p. 1286-1287.

Nielsen, K.R., 1995, [preprint] Colorado nahcolite: a low cost source of sodium chemicals: Industrial Mineral '95, October 17-18, 1995, Vancouver, Canada, 9 p.

Phillips, T.E., 1976, A survey of potential methods for resource recovery from black water of the upper Green River Basin: Univ. of Wyoming M.S. thesis, Laramie, 74 p.

Phillips, T.E., 1978, Potential methods for resource recovery from black trona water of the northern Green River Basin of Wyoming: U.S. Dept. Energy Laramie Energy Tech. Center LETC/RI 78/21, 25 p.

Scott, R.W., Jr., and Pantea, M.P., 1982a, Results of USGS oil-shale core drilling in the eastern Uinta Basin: Red Wash-1 drill hole: U.S. Geological Survey Open-File Report 82-965, 38 p.

Scott, R.W., Jr., and Pantea, M.P., 1982b, Results of USGS oil-shale core drilling in the eastern Uinta Basin: Coyote Wash-1 drill hole: U.S. Geological Survey Open-File Report 82-966, 58 p. 
Trudell, L.G., 1975, Lithologic description of samples submitted for assay from Union Pacific Railroad Company's El Paso 44-3 corehole drilled in C SE1/4 $\mathrm{SE}^{1} / 4$ of sec. 3, T.15 N., R.109 W., Sweetwater County, Wyoming: U.S. Bureau of Mines Laramie Energy Research Center, Illustration SBR-4751P, 57 p.

Wiig, S.V., Grundy, W.D., and Dyni, J.R., 1995, Trona resources in the Green River Basin, southwest Wyoming: U.S. Geological Survey Open-File Report 95-476, 88 p. 